DOE/BC/W-109-ENG-38-4

Distribution Category UC-122

Disposal of Norm-Contaminated Oil Field Wastes in Salt Caverns

By

John A. Veil, Karen P. Smith, David Tomasko

Deborah Elcock, Deborah L. Blunt and Gustavious P. Williams

January 1999

Work Performed Under Contract W-31-109-ENG-38

Prepared for

U.S. Department of Energy

Assistant Secretary for Fossil Energy

John K. Ford, Technology Manager

National Petroleum Technology Office

P.O. Box 3628

Tulsa, OK 74101

Prepared by

Argonne National Lab

955 L'Enfant Plaza SW

Suite 6000

Washington, DC 20024 



\section{DISCLAIMER}

This report was prepared as an account of work sponsored by an agency of the United States Government. Neither the United States Government nor any agency thereof, nor any of their employees, make any warranty, express or implied, or assumes any legal liability or responsibility for the accuracy, completeness, or usefulness of any information, apparatus, product, or process disclosed, or represents that its use would not infringe privately owned rights. Reference herein to any specific commercial product, process, or service by trade name, trademark, manufacturer, or otherwise does not necessarily constitute or imply its endorsement, recommendation, or favoring by the United States Government or any agency thereof. The views and opinions of authors expressed herein do not necessarily state or reflect those of the United States Government or any agency thereof. 


\section{DISCLAIMER}

Portions of this document may be illegible in electronic image products. Images are produced from the best available original document. 


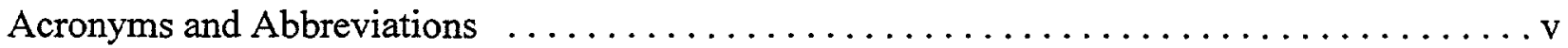

Executive Summary $\ldots \ldots \ldots \ldots \ldots \ldots \ldots \ldots \ldots \ldots \ldots \ldots \ldots \ldots$ vii

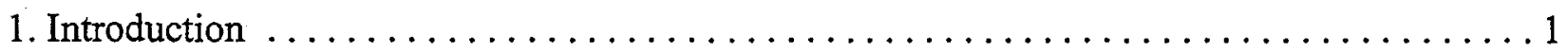

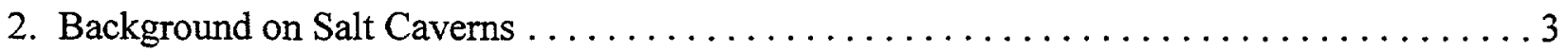

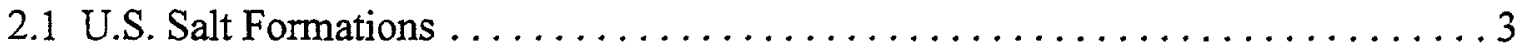

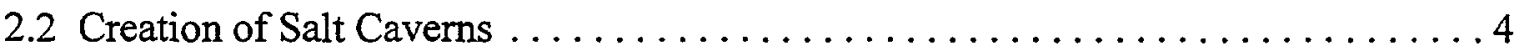

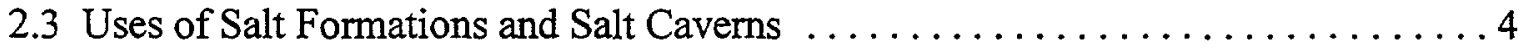

2.4 Waste Disposal in Caverns . . . . . . . . . . . . . . . . . . . 5

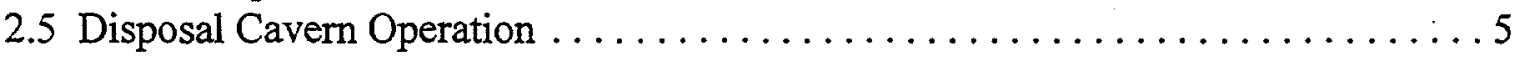

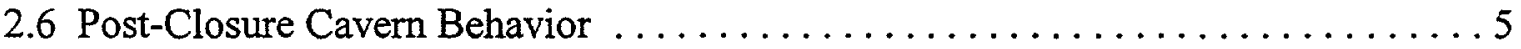

3. Hydrogeology $\ldots \ldots \ldots \ldots \ldots \ldots \ldots \ldots \ldots \ldots \ldots \ldots \ldots \ldots \ldots \ldots \ldots \ldots$

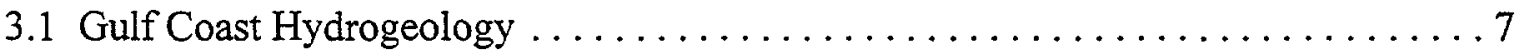

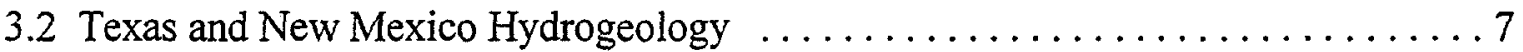

4. Regulatory Considerations . . . . . . . . . . . . . . . . . . . . . 11

4.1 Hazardous Waste Status of NOW and NORM Waste $\ldots \ldots \ldots \ldots \ldots \ldots \ldots 1$

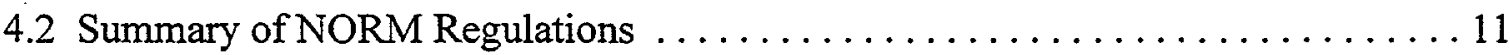

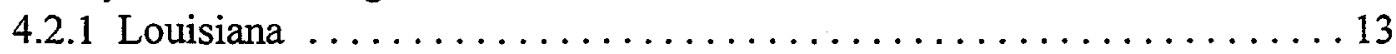

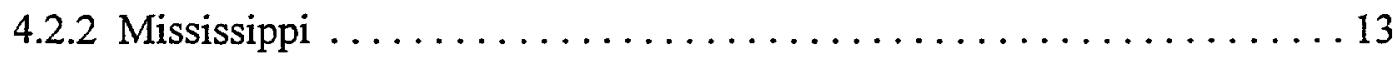

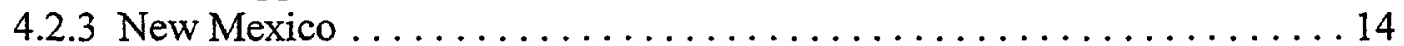

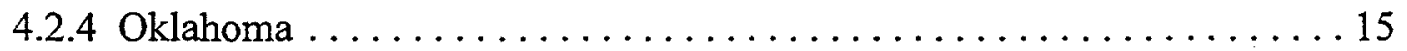

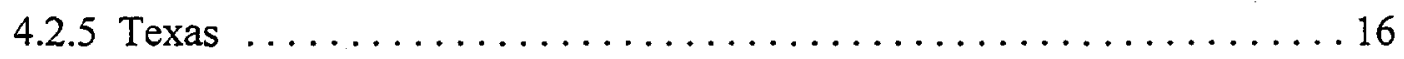

4.3 Salt Caverns and the Underground Injection Control Program . . . . . . . . 16

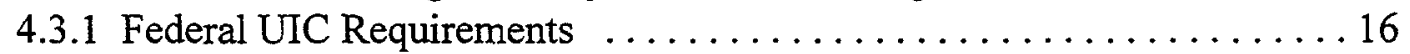

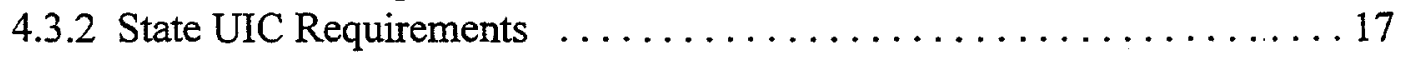

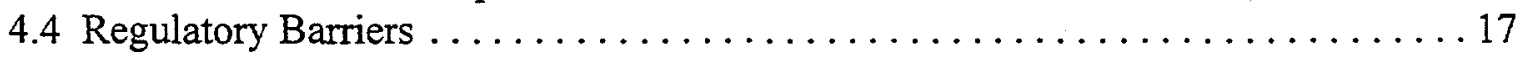

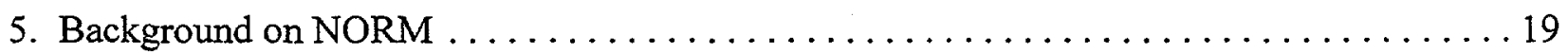

5.1 NORM Occurrence and Chemistry . . . . . . . . . . . . . . . 19

5.2 NORM Management Practices . . . . . . . . . . . . . . . . . . 20

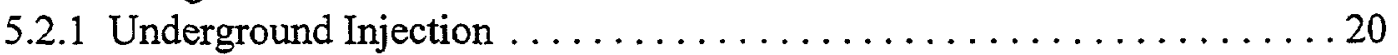

5.2 .2 Landfill Disposal . . . . . . . . . . . . . . . . . . . 21

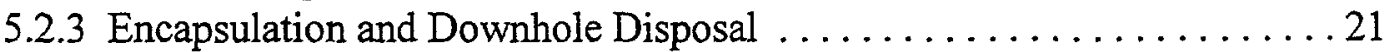

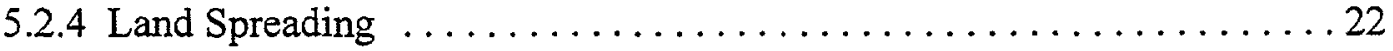

6. Technical Feasibility of NORM Waste Disposal in Salt Caverns . . . . . . . . . . . 23 


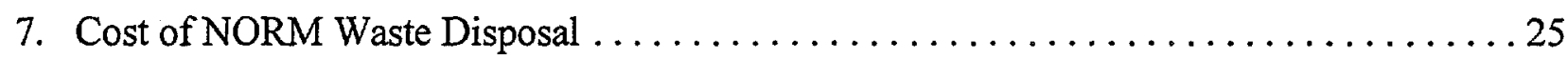

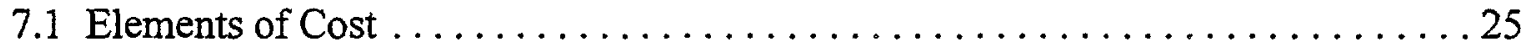

7.2 Historical NORM Waste Disposal Costs . . . . . . . . . . . . . . . . 25

7.3 Current NORM Waste Disposal Costs . ....................... 25

7.3.1 Costs for Off-site Commercial Disposal of NORM Waste $\ldots \ldots \ldots \ldots 26$

7.3.2 Costs for On-site Commercial Disposal of NORM Waste $\ldots \ldots \ldots .26$

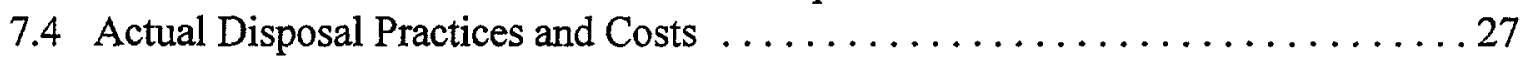

7.5 Prospects for Cost-Effective NORM Waste Disposal in Salt Caverns . . . . . . . . 28

8. Risks from Disposal of NORM Waste in Salt Caverns $\ldots \ldots \ldots \ldots \ldots \ldots \ldots \ldots \ldots \ldots$

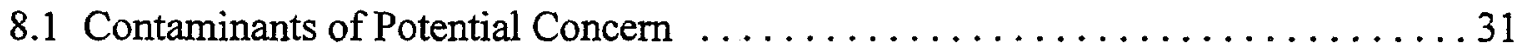

8.2 Contaminant Concentrations at the Time of the Release $\ldots \ldots \ldots \ldots \ldots \ldots . \ldots . \ldots . \ldots 32$

8.3 Fate and Transport for Contaminants of Potential Concern ............... 32

8.4 Exposure Assessment . ................................... 34

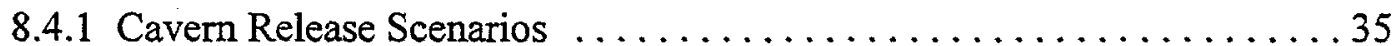

8.4.2 Probabilities of Occurrence ....................... 40

8.4.3 Exposure Point Concentrations ..................... 41

8.4.4 Estimation of Radiological Doses and Carcinogenic Risks . . . . . . . . . 41

8.5 Uncertainties . . . . . . . . . . . . . . . . . . . . . . . . . . . . 44

8.6 Sensitivity of Risks to Operating Procedures and Regulatory Structures . . . . . . 44

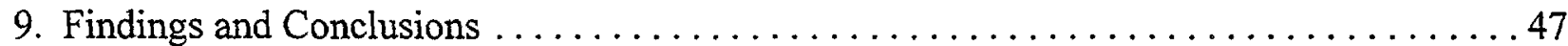

9.1 Technical Feasibility . . . . . . . . . . . . . . . . . . . . . . . . 47

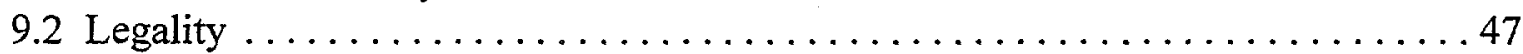

9.3 Economics ......................................... 47

9.4 Human Health Risk . . . . . . . . . . . . . . . . . . . . . . . . . . . . . . 48

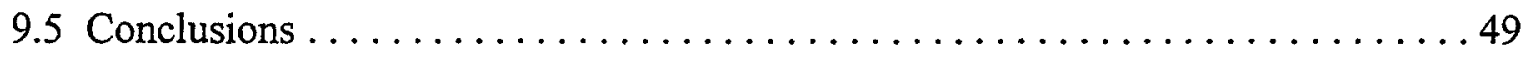

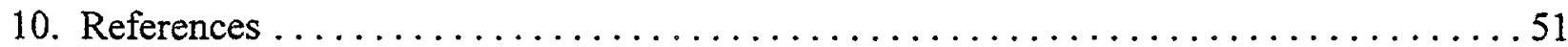

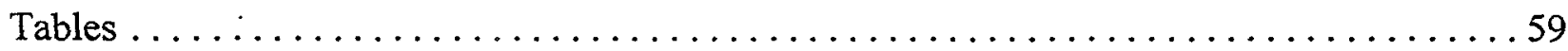




\section{Acronyms and Abbreviations}

API American Petroleum Institute

CEDE committed effective dose equivalent

CERCLA Comprehensive Environmental Response, Compensation, and Liability Act

CSA Canadian Standards Association

DCF dose conversion factor

DOE U.S. Department of Energy

EPA U.S. Environmental Protection Agency

ESR Early Storage Reserve

GCC RASA Gulf Coast Regional Aquifer-System Analysis

ICRP International Commission on Radiological Protection

IOGCC

LAC Interstate Oil and Gas Compact Commission

LDEQ Louisiana Administrative Code

LDNR Louisiana Department of Environmental Quality

LPG Louisiana Department of Natural Resources

$\mathrm{MCL}$ liquified petroleum gas

MDEQ maximum contaminant levels

NMAC Michigan Department of Environmental Quality

NMED New Mexico Administrative Code

NORM

NOW New Mexico Environment Department

NRC naturally occurring radioactive materials nonhazardous oil field wastes

$\mathrm{OCC}$ U.S. Nuclear Regulatory Commission

OCD Oklahoma Corporation Commission

RCRA Resource Conservation and Recovery Act

RMLLRWB Rocky Mountain Low-Level Radioactive Waste Board SDWA Safe Drinking Water Act SPR Strategic Petroleum Reserve

TAC Texas Administrative Code

TRC Texas Railroad Commission

UIC Underground Injection Control

WIPP

Waste Isolation Pilot Plant 



\title{
Disposal of NORM-Contaminated Oil Field Wastes in Salt Caverns
}

\author{
John A. Veil, Karen P. Smith, David Tomasko, Deborah Elcock, \\ Deborah L. Blunt, and Gustavious P. Williams
}

\section{Executive Summary}

Salt caverns have been used for several decades to store various hydrocarbon products. In the past few years, four facilities in the United States have been permitted to dispose of nonhazardous oil field wastes (NOW) in salt caverns. Several other disposal caverns have been permitted in Canada and in Europe for similar wastes. To date, caverns have not been used to dispose of oil field wastes that have been contaminated with naturally occurring radioactive materials (NORM). There are only a few approved methods for disposing of NORM wastes and only a handful of commercial disposal facilities that are licensed to accept NORM waste. This report evaluates the feasibility, legality, economics, and human health risk of disposing of NORM-contaminated oil field wastes in salt caverns.

Oil and gas production and processing operations sometimes accumulate NORM at elevated concentrations in by-product waste streams. The sources of most of the radioactivity are isotopes of uranium-238 (U-238) and thorium-232 (Th-232), which are naturally present in subsurface formations from which oil and gas are produced. The primary radionuclides of concern in NORM wastes are radium-226 (Ra-226) of the U-238 decay series and radium-228 (Ra-228) of the Th-232 decay series. Other radionuclides of concern include radionuclides that form from the decay of Ra-226 and Ra-228, such as radon-222 (Rn-222). The production waste streams most likely to be contaminated by elevated radium concentrations include produced water, scale, and sludge. Spills or intentional releases of these wastes to the ground can result in NORM-contaminated soils that must also be disposed of.

Currently, no federal regulations specifically address handling and disposal of NORM wastes. In the absence of federal regulations, individual states have taken responsibility for developing their own regulatory programs. These programs have been evolving rapidly over the last few years. The existing state regulatory programs establish requirements for (1) NORM exemption standards or action levels; (2) licensing of parties possessing, handling, or disposing of NORM waste; (3) the release of NORM-contaminated equipment and land; (4) worker protection; and (5) NORM waste disposal. This study evaluates the potential for salt cavern disposal of NORM waste in five states that have existing or proposed NORM disposal regulations and that have expressed serious interest in disposal of NOW in salt caverns. These states are Louisiana, Mississippi, New Mexico, Oklahoma, and Texas. Each of these state programs addresses the disposal of NORM waste into Class II injection wells, either directly or indirectly. The regulation of underground injection of NORM waste is relevant to the potential

$$
\text { vii }
$$


disposal of NORM waste in salt caverns, because disposal into salt caverns is considered by most states to equate to underground injection into Class II wells. A review of federal regulations and regulations from the five states listed above indicated that there are no outright prohibitions against NORM disposal in salt caverns or other Class II wells, except for Louisiana, which prohibits disposal of radioactive wastes or other radioactive materials in salt domes. Presently, however, only Texas and New Mexico are working on disposal cavern regulations, and no states have issued permits to allow cavern disposal of NORM waste.

Most NORM-contaminated produced water is disposed on-site through injection wells and is not the primary focus of this report. Other types of NORM waste are presently disposed of both on oil production sites and at off-site commercial disposal facilities. A majority of these NORM wastes are disposed of through underground injection, a significant portion of which presently takes place at a commercial injection facility located in eastern Texas. Several companies offer the service of coming to an operator's site, grinding the NORM waste into a fine particle size, slurrying the waste, and injecting it into the operator's own disposal well. One company is developing a process in which the radionuclides are dissolved out of the NORM wastes, thereby leaving NOW and a contaminated liquid stream that is injected into the operator's own injection well. Smaller quantities of NORM are disposed of through burial in landfills, encapsulation inside the casing of wells that are being plugged and abandoned, or land spreading.

It appears that disposal of NORM waste in salt caverns is technically feasible because the NORM waste is physically and chemically similar to NOW, which is already being disposed of in salt caverns. Its primary difference from NOW is the presence of radionuclides in NORM. The presence of radionuclides may require additional safety precautions when handling the NORM waste, but the actual disposal would be no different from NOW.

It is difficult to quantify the total cost for disposing of NORM waste. The cost components that must be considered, in addition to the actual disposal cost, include analytical costs, transportation costs, container decontamination costs, and possibly permitting costs. One other cost component that cannot readily be quantified, but is important nonetheless, is the potential for long-term liability if the disposal site eventually causes environmental contamination and is subject to a Superfund cleanup. Current NORM waste disposal costs range from $\$ 15 / \mathrm{bbl}$ to $\$ 420 / \mathrm{bbl}$. The costs presented in this study reflect the information provided by disposal companies to the authors in early 1998 and may not reflect actual total disposal costs. It is also difficult to compare cost figures from one disposal company with those of another company because the companies do not always include the same types of services in their quoted prices.

Operators of the four permitted disposal caverns in Texas were contacted to see if they had made any estimates of what they might charge customers if they were authorized to accept NORM wastes. They currently charge from $\$ 1.95 / \mathrm{bbl}$ to $\$ 6 / \mathrm{bbl}$ to dispose of NOW wastes. To be authorized to dispose of NORM wastes, cavern operators would need to upgrade their 
aboveground waste handling facilities and analytical capabilities, among other things. Although none of the cavern operators had even preliminary cost estimates, one operator believed that he could realistically operate at costs below $\$ 150 / \mathrm{bbl}$, the cost charged by the company receiving the majority of NORM waste in this country. He also noted that if regulatory agencies allow NORM disposal in caverns, competition would drive the price lower (Moore 1998). NOW disposal caverns have proven cost-competitive with other NOW disposal facilities in the same geographic area. This study does not constitute a formal market analysis, and the costs to upgrade a cavern disposal operation for NOW to one that disposes of NORM waste have not been quantified. Nevertheless, there is a reasonable chance that NORM waste disposal caverns would be able to compete economically with existing off-site commercial NORM disposal facilities once regulatory agencies allow the practice to occur.

Argonne National Laboratory (Argonne) has previously analyzed the potential radiological doses associated with several disposal methods, including underground injection into Class II disposal wells (Smith et al. 1996). Recently, Argonne completed an analysis of the potential human health risks resulting from exposure to contaminants released from the caverns in domal salt formations used for NOW disposal (Tomasko et al. 1997). The evaluation assumes normal operations but considers the possibility of leaks in cavern seals and cavern walls during the post-closure phase of operation. The current study builds on the previous Argonne work in NORM risk assessment and salt cavern disposal and follows the Tomasko et al. (1997) methodology to the extent possible. NORM waste contains the same chemical contaminants as NOW but also contains radionuclides. The risk from the chemical contaminants in NORM remains the same as the risk estimated for NOW (Tomasko et al. 1997). In this study, a separate radiological risk analysis was performed. Initially, several radionuclides were considered as potential contaminants of concern for the assessment. All but two of these were subsequently dropped from further consideration because of low predicted activities produced by a combination of their high retardation coefficients and short half-lives at a time of 1,000 years in the future, the time frame selected for the risk analyses. The remaining contaminants were Ra226 and $\mathrm{Rn}-222$ :

The release scenarios considered in both the NOW analysis and this study included inadvertent intrusion by unintentionally drilling a well into a closed cavern; failure of the cavern seal because of increased pressure from salt creep and geothermal heating; release of contaminated fluid through cracks, leaky interbeds, or nonhomogeneous zones composed of higher permeability material; and partial cavern roof fall. Most releases would be to deep aquifers at or near the top of the cavern, although under two scenarios, released contaminants could move upward through the well casing and leak into shallow aquifers. To be consistent with Tomasko et al. (1997), the probability of cavern failure was based on "best-estimate" and "worst-case" estimates provided by a panel of experts. Averaged best-estimates for the different scenarios ranged from 0.006 for partial roof fall plus cavern seal failure and fluid release at shallow depth to 0.1 for partial roof fall plus fluid release at depth. Averaged worst-case estimates ranged from 0.04 for seal failure with fluid release at shallow depth, to 0.29 for partial roof fall plus fluid release at depth. To provide an even more conservative estimate, we used the 
true worst-case condition - the $100 \%$ Probability of Release case - under which all caverns release fluids during the 1,000-year period of concern.

Once contaminated fluids leave the cavern, they are expected to migrate laterally through different formations and aquifers. During the time the fluids travel from the point of release to the receptor site (assumed to be $1,000 \mathrm{ft}$ laterally from the cavern at either the depth of the cavern $[1,000 \mathrm{ft}]$ or a shallow depth [50 ft]), various physical, chemical, biological, and radiological processes occur that reduce the concentration of the contaminants. Fate and transport modeling was used to estimate the contaminant concentrations at the receptor point (exposure point concentrations).

Risk calculations were then conducted on the basis of the exposure point concentrations and standard assumptions regarding drinking water intake rates, exposure time, duration, and frequency. The risk was estimated for persons who, during the next 1,000 years, drink groundwater taken from a well at the receptor site. The estimated worst-case cancer risks from the chemical contaminants of NORM waste are very low $\left(1 \times 10^{-8}\right.$ to $\left.2 \times 10^{-17}\right)$, and even under the extremely conservative $100 \%$ Probability of Release case, the highest chemical contaminant risk is $2 \times 10^{-7}$. The excess cancer risks estimated for the radiological contaminants are orders of magnitude lower; even for the $100 \%$ Probability of Release case, risks are $1 \times 10^{-13}$ to $3 \times 10^{-22}$, and, consequently, are dwarfed by the risks from the chemical contaminants.

The risk calculations are intended to estimate the risk over the 1,000 years following cavern sealing. It is unlikely that an abandoned cavern would begin leaking immediately. Leakage, if it occurred, would most likely begin many years after the cavern was sealed. The fate and transport models, however, estimate the concentration of contaminants at a time 1,000 years after the release of contaminants, not after cavern sealing. Therefore, the risk estimates are effectively measuring the risk over a period of time longer than 1,000 years. This procedure provides an additional measure of conservatism to the risk estimates.

The size of the hypothetical cavern used in these risk calculations (one million $\mathrm{ft}^{3}$ ) is, for the sake of consistency, the same as was used in Tomasko et al. (1997). The hypothetical cavern is somewhat smaller than the existing disposal caverns in Texas. The volume of fluid potentially released from the cavern is proportional to the volume of the cavern that is filled with fluid; therefore, larger caverns would release proportionately more fluid. Because actual cavern volumes are on the same order of magnitude as the hypothetical cavern, the fluid volumes released and the estimated risks from the actual caverns are expected to be on the same order of magnitude as those calculated here, which remain lower than accepted risk thresholds.

The use of the results of this report include a number of caveats. First, the assessment does not address risks to workers at the cavern disposal site. Smith et al. (1996) estimate radiation doses to workers involved in cleaning pipes, cleaning vessels, and working in storage yards where NORM-contaminated equipment is cleaned prior to NORM waste disposal. The risk to workers is likely to be the same regardless of the ultimate disposal method used. Second, 
the assessment does not determine whether any health effects will occur in the future; it only estimates cancer risk and potential for noncancer effects. Third, risks have only been estimated for contaminants for which toxicity values were available; just because there is no toxicity value does not mean there is no risk.

The approach used in this study is subject to several uncertainties that could affect the results. These uncertainties include an extrapolation from high levels to low levels of radiation exposure, the necessity to model exposure data because no cavern exposure data exist, and the difficulty in distinguishing background concentrations of radionuclides from introduced concentrations. 


\section{Introduction}

In 1995, the U.S. Department of Energy (DOE), Office of Fossil Energy, asked Argonne National Laboratory (Argonne) to conduct a preliminary technical and legal evaluation of disposing of nonhazardous oil field waste (NOW) into salt caverns. That study concluded that disposal of NOW into salt caverns is feasible and legal. If caverns are sited and designed well, operated carefully, closed properly, and monitored routinely, they can be a suitable means of disposing of NOW (Veil et al. 1996). Considering these findings and the increased U.S. interest in using salt caverns for NOW disposal, the Office of Fossil Energy asked Argonne to conduct further research on the cost of cavern disposal compared with the cost of more traditional NOW disposal methods and on preliminary identification and investigation of the risks associated with such disposal. The cost study (Veil 1997) found that disposal costs at the four permitted disposal caverns in the United States were comparable to or lower than the costs of other disposal facilities in the same geographic area. The risk study (Tomasko et al. 1997) estimated that both cancer and noncancer human health risks from drinking water that had been contaminated by releases of cavern contents were significantly lower than the accepted risk thresholds.

Since 1992, DOE has funded Argonne to conduct a series of studies evaluating issues related to management and disposal of oil field wastes contaminated with naturally occurring radioactive material (NORM). Included among these studies were radiological dose assessments of several different NORM disposal options (Smith et al. 1996).

In 1997, DOE asked Argonne to conduct additional analyses on waste disposal in salt caverns, except that this time the wastes to be evaluated would be those types of oil field wastes that are contaminated by NORM. This report describes these analyses. Throughout the remainder of this report, the term "NORM waste" is used to mean "oil field waste contaminated by NORM".

The remainder of this report consists of eight sections. Section 2 provides background on the development, use, and closure of salt caverns that may be used for disposal of NORM waste. Section 3 describes specific hydrogeologic conditions of locations where salt caverns are most likely to be used for oil field disposal. Section 4 provides background information on NORM occurrence and chemistry and existing NORM waste management practices. Chapter 5 assesses the feasibility of disposing of NORM waste in salt caverns. Chapter 6 outlines the state and federal regulations that affect cavern disposal of NORM waste. Chapter 7 summarizes the costs associated with disposing of NORM wastes. Chapter 8 describes the analysis used to assess the risks associated with cavern disposal of NORM waste. Finally, Section 9 summarizes the results of the analyses. 



\section{Background on Salt Caverns}

\subsection{U.S. Salt Formations}

Salt deposits occur in two major forms in the United States: bedded salt and salt domes. Although salt deposits occur in many parts of the United States, the occurrence of salt in quantities and locations that would promote commercial development is limited. Figure 1 (from Veil et al. 1996) shows the location of the major U.S. subsurface salt deposits. In 16 states salt occurs in sufficient quantity to be mined by either excavation or solution mining or to be recovered through solar evaporation. These states with major salt deposits are Alabama, Arizona, Colorado, Kansas, Louisiana, Michigan, Mississippi, Montana, New Mexico, New York, North Dakota, Ohio, Oklahoma, Pennsylvania, Texas, and Utah (Veil et al. 1996).

Bedded salt formations occur in layers interspersed with such sedimentary materials as anhydrite, shale, dolomite, and other more soluble salts (e.g., potassium chloride). These materials have varying degrees of permeability, but all are generally low (Freeze and Cherry 1979). The bedded salt deposits are tabular and can contain significant quantities of impurities.

Salt domes are large, nearly homogeneous formations of sodium chloride, although they may contain nonhomogeneous zones. Pfeifle et al. (1995) report that the typical anhydrite $\left(\mathrm{CaSO}_{4}\right)$ content of Gulf Coast salt domes averages less than $5 \%$. Salt domes were created by geological processes that spanned millions of years (Chilingarian et al. 1989). Approximately 30 million years ago, salt buried by more dense materials flowed to form pillows. Because of its lower density, salt flowed upward to form diapirs (domes or anticlinal folds whose overlying rocks have been ruptured by the squeezing up of the more plastic salt core) and pierced overlying units.

As the salt passed upward through the overlying sediments, long, finger-like projections developed. The depth of the intruded salt (sedimentary piercements) can be greater than 10,000 $\mathrm{ft}$ (Whiting 1981), and the top width of the salt domes ranges from about 0.5 to 2.5 miles (Chilingarian et al. 1989). If the intruded salt contacted undersaturated water, dissolution.would occur. Through a complex interaction of dissolution, recrystallization, hydration of anhydrite to form gypsum, sulfate reduction, cementation, etc., a caprock was often formed. Although caprocks are common in the vicinity of salt domes, they are not always present (Linn 1997).

At the top of the caprock, a region of limestone frequently developed. This limestone may have been formed by a number of processes, including reduction of the calcium-sulfate caprock and precipitation from calcium-sulfate-rich water (Werner 1986). 


\subsection{Creation of Salt Caverns}

To create salt caverns, water that is not fully salt-saturated is injected into a salt stock, and the resulting brine solution is withdrawn. This method is referred to as solution mining (Testa 1994). The development and shape of the salt cavern can be controlled by the method used for construction. In the direct circulation method, fresh water is injected through a tubing string from the surface, and brine is withdrawn through an annular space between the tubing and final casing. In the reverse circulation method, fresh water enters through the annulus, and brine is removed through the tubing string. A combination of these two methods, or other more complicated methods, can be used to obtain a desired cavern shape. The American Petroleum Institute (API) provides illustrations and more details on these methods (API 1994). Figures 2 and 3, taken from Veil et al. (1996), provide general schematic drawings of salt caverns used for waste disposal for caverns in domal salt and bedded salt, respectively. These figures are not drawn to scale or intended to show detailed construction features.

The petroleum industry has constructed many salt caverns for storing hydrocarbons. Several organizations have developed standards and guidance for designing and operating hydrocarbon storage salt caverns (CSA 1993; API 1994; IOGCC 1995). Readers desiring more details on design, location, and construction of salt caverns are referred to these reports.

\subsection{Uses of Salt Formations and Salt Caverns}

As salt intruded the Cenozoic sediments along the Gulf Coast, various minerals were often precipitated in the vicinity of the caprock. Along with the minerals, oil was frequently trapped under the edge of the caprock. Because of the high probability of finding oil and other valuable minerals, salt domes have been extensively explored and mined for more than 100 years. Starting in the late 1800 s, salt domes were commercially mined for salt by various leaching techniques. The shapes of the resulting caverns were often irregular because of the techniques applied, but a number of caverns, such as West Hackberry Cavern 11, are nearly symmetrical (Tomasko 1985).

Salt caverns are used for storing hydrocarbons. The earliest cavern storage in salt domes for liquefied petroleum gas (LPG) started in 1951; LPG storage in bedded salt started somewhat sooner, in the early 1940s (Querio 1980). Some of the liquified products stored include propane, butane, ethane, fuel oil, gas, and crude oil. Private industry in the United States operates a large number of caverns for storing liquid petroleum products, petrochemicals, and natural gas.

DOE acquired the rights to some existing caverns for the Early Storage Reserve (ESR) of the Strategic Petroleum Reserve (SPR). The ESR was designed to store 250 million barrels of oil, about two-thirds of which were to be placed in solution-mined caverns and one-third in a conventional rock salt mine. Acquisitions for the ESR were made about 1977. The SPR now has a capacity of 680 million barrels, and the rock salt mine has been removed from the program (Diamond 1997). 


\subsection{Waste Disposal in Caverns}

Use of salt caverns for waste disposal in the United States has been limited. A summary of current waste disposal practices, exclusive of NORM wastes, is given in Veil et al. (1996), along with a discussion on using caverns for waste disposal in Canada, the United Kingdom, Germany, the Netherlands, and Mexico. In the United States, the Railroad Commission of Texas has issued six permits for disposal of NOW in salt caverns; four of these are operational. None of the six Texas facilities are authorized to dispose of NORM wastes in their caverns. NORM wastes are not approved for cavern disposal in Canada or the United Kingdom. To the authors' knowledge, NORM wastes are not being disposed of in salt caverns anywhere in the world at this time.

\subsection{Disposal Cavern Operation}

Initially, the caverns would be filled with brine. Wastes would then be introduced as a slurry of waste and a fluid carrier (brine or fresh water). Three scenarios are possible for introducing the waste material: (1) the waste can be pumped down tubing to the bottom of the cavern and the displaced brine can be withdrawn through an annulus; (2) the waste can be pumped down an annulus and the displaced brine can be withdrawn through the tubing; and (3) the waste can be injected through one well and the brine withdrawn from another well.

As the slurry is injected, the cavern acts as an oil/water/solids separator. The heavier solids sink to the bottom of the cavern and form a pile. Any free oils and hydrocarbons float to the top of the cavern because they are less dense than water. An organic blanket could be injected into the cavern to prevent additional leaching of the cavern's roof by water that is not fully saturated with salt. Clays in the slurry and dissolved chemical constituents from the waste can mix with the brine, forming a suspension above a brine/waste interface. Clean brine displaced by the incoming slurry would be removed from the cavern and either sold as a product or disposed of in an injection well.

Early in the life of the disposal cavern, clean brine is withdrawn from hundreds of feet above the surface of the waste pile or interface. As the cavern fills, the brine becomes dirtier (i.e., it will have a higher clay, oil, and dissolved waste constituent content). This dirty brine can produce operational difficulties (e.g., clogging of pumps) and additional expenses (Veil et al. 1996). The cavern is considered to be "full" of waste when return of disposed material with the displaced fluid becomes a problem. When the cavern is full, the operator seals the cavern.

\subsection{Post-Closure Cavern Behavior}

Once the cavern had been filled with waste, the cavern would be sealed and the borehole plugged with cement. Plugs would be placed in the well bore above and below water-bearing intervals to isolate these intervals permanently. 
A waste-filled cavern that has been sealed is subject to a number of complex physical processes: reduction in cavern volume caused by salt creep (the process by which salt surrounding the cavern flows into the cavern space as a pseudofluid [Bishop 1986; Freeze et al. 1995]); convective mixing in the upper, brine-filled portion of the cavern; differential settling and compaction of solids; chemical reaction and compaction of the waste material; and an increase in pressure produced by the combined effects of salt creep and the addition of sensible heat (heat derived from the geothermal gradient vertically across the cavern - approximately $13^{\circ} \mathrm{F}$ per $1,000 \mathrm{ft}$ at a depth of $1,000 \mathrm{ft}$ [Tomasko 1985]).

During a transient period of several years after closure of a cavern filled with brine, pressure can exceed the lithostatic value (pressure in surrounding salt) because of thermal expansion of the brine. The amount of overpressurization is a function of cavern size (Berest and Brouard 1995). Similarly, cavern pressure can exceed the lithostatic value after a longer time period when, due to salt creep, brine pressure will balance average lithostatic pressure, resulting in a slight excess of brine pressure at the top of the cavern (Langer et al. 1984; Wallner 1986). This overpressurization occurs because lithostatic pressure increases linearly with depth, whereas brine pressure is constant within the cavern.

The presence of a small quantity of gas in the sealed cavern can mitigate the effects of pressure buildup because the gas drastically increases the cavern compressibility (Berest et al. 1997). Tomasko et al. (1997) discuss several ways in which gases could potentially be produced in a sealed disposal cavern, including bacterial degradation of the waste, corrosion, and natural releases from the salt formation itself (e.g., carbon dioxide, hydrogen sulfide, hydrogen, methane, etc.), but conclude that significant gas production is unlikely.

A recent study of the behavior of brine-filled, sealed caverns suggests that the permeability of the material surrounding the cavern can also influence pressure buildup (Wallner and Paar 1997). Because of a very slow pressure increase within a sealed salt cavern, the pressure at the top of the cavern would only exceed the lithostatic value after a long time (on the order of thousands of years for a 1,000-ft-tall cavern). Because the rock salt formation could become permeable if the fluid pressure exceeded the stress in the salt, small leakage rates of fluids from the top of the cavern are predicted. This leakage would compensate for the overpressurization at the top of the cavern and return the system to an equilibrium condition.

Although the pressurization of sealed caverns containing liquids or dry granular wastes is currently under investigation (e.g., Langer et al. 1984; Wallner 1986; Berest and Brouard 1995; Wallner and Paar 1997; Berest et al. 1997), little research has been directed at predicting pressure behavior in caverns containing a combination of NORM and NOW. Cavern behavior is expected to be similar to that discussed above, with the exception that the compressibility of the wastes may alter the time scale and magnitude of the system response. More study of actual waste disposal caverns would help to clarify this issue. 


\section{Hydrogeology}

Most salt formations of interest for NOW and NORM waste disposal occur along the Gulf Coast in Texas and Louisiana, the Permian Basin of New Mexico, and in other states, such as Kansas and Michigan, that have salt domes. The following subsections discuss hydrogeological conditions for the Gulf Coast, the western Texas panhandle, and New Mexico. A composite of these areas is then used as the basis for the generic risk analysis described in Section 8. This information is particularly useful in calculating the fate and transport of contaminants that are released from caverns.

\subsection{Gulf Coast Hydrogeology}

Salt domes along the Gulf Coast of the United States are located in the Coastal Plain Physiographic Province (Back et al. 1988). This province is underlain by a gulfward thickening wedge of unconsolidated to semiconsolidated sedimentary rocks (sand, silt, and clay derived from erosion of nearby continental upland areas). These sediments overlie consolidated rocks of Mesozoic Age and range in thickness from a few feet near their landward limit to more than $30,000 \mathrm{ft}$ in southern Louisiana.

As part of the Gulf Coast Regional Aquifer-System Analysis (GCC RASA) program, the depth to groundwater was evaluated for a 230,000-square-mile study area that included coastal regions in Texas, Louisiana, Mississippi, and Florida (Williams and Williamson 1989). On the basis of data from 6,825 wells, the depth to the water table ranges from 0 to $74 \mathrm{ft}$, with a median value of $20 \mathrm{ft}$. This shallow groundwater system is composed primarily of sands interbedded with deposits of silt and clay. Where the silts and clay have been eroded and the aquifer is in communication with the atmosphere, the aquifer is unconfined. Confined to semiconfined conditions exist where low-permeability clays and silt overlay the more permeable sands (Hanor 1993). Beneath the shallow groundwater system are other sequences of clays and silts, interspersed with beds of sand. The sand areas constitute other potential aquifers that are predominantly confined (Capuano and Jan 1996).

Recharge to the shallow groundwater system is derived from precipitation. The majority of recharge occurs in areas where the clay and silt layers are absent. Discharge of this aquifer occurs to surface waters, underlying deeper aquifers, and pumping wells.

\subsection{Texas and New Mexico Hydrogeology}

Bedded salt occurs in the Texas panhandle area and West Texas, as well as in central and southeastern New Mexico. These bedded salts are located, for the most part, in deep formations (the top of salt occurs at a depth of 500 to 2,000 ft below the land surface, and the salt is about 1,000 to $3,000 \mathrm{ft}$ thick). Although most of these bedded salts occur below $1,000 \mathrm{ft}$, some in West 
Texas can be much shallower (e.g., one of the West Texas disposal caverns starts at a depth of about $700 \mathrm{ft}$ [Hickerson 1995]).

Overlying the bedded salt layers are the Ogallala fluvial aquifer, which is composed of stream and river deposits, and the Dockum aquifer, which is composed of fluvial and lacustrine (lake) deposits (Bassett and Bentley 1982). These aquifers make up a shallow, freshwater system that is used for domestic, municipal, industrial, and agricultural purposes. The combined thickness of these two aquifers can be as great as 2,300 $\mathrm{ft}$ (Bair et al. 1985). The Ogallala is the shallower of the two aquifers and occurs at a depth ranging between 20 and $400 \mathrm{ft}$ (Wood and Sanford 1995). It ranges from 0 to $800 \mathrm{ft}$ thick (Seni 1980), and it underlies about 134,000 square miles of land from Nebraska to New Mexico (Back et al. 1988). Its principal composition is sand and gravel. Groundwater velocity in this aquifer is estimated to be about $100 \mathrm{ft} /$ year.

The Dockum aquifer lies below the Ogallala aquifer. Locally, its depth is variable; it can outcrop at the surface or occur as deep as $800 \mathrm{ft}$ below the ground. It is typically composed of a sandstone and conglomerate unit (fluvial) overlying a fine silt and clay unit (lacustrine). The thick Permian evaporite-bearing unit beneath the Dockum is an aquitard and a barrier to vertical groundwater flow. Depth to bedded salt ranges from about 500 to $2,000 \mathrm{ft}$. The uppermost extensive salt is the Salado Formation. Where this unit has been dissolved, various older formations (e.g., Seven Rivers, Grayburg, San Andres, and Castile) contain the uppermost salt units. In some areas, salt has been completely removed. At the depth of the salt, the velocity of groundwater is estimated to be about $10 \mathrm{ft} /$ year.

Bedded salts are being developed for low-level nuclear waste disposal at the Waste Isolation Pilot Plant (WIPP) in New Mexico. This facility has been constructed and will shortly begin operation. It is located at a depth of $2,150 \mathrm{ft}$ below the ground surface in the Salado Formation (DOE 1990). The Ogallala and Dockum aquifers are absent in this area of New Mexico, and the shallowest groundwater of consequence occurs in the Culebra Dolomite of the Rustler Formation at a depth of about $750 \mathrm{ft}$.

Recharge to the shallow groundwater system in the semiarid Texas/New Mexico environment is derived from precipitation. Wood and Sanford (1995) estimate the annual recharge to be $11 \pm 2 \mathrm{~mm} / \mathrm{yr}$. Recharge is small because of high potential evaporation, plant transpiration, limited precipitation, and runoff. In the past, discharge was to springs; other, deeper, groundwater systems; and pumps. Because of heavy pumping, most of the discharge springs are now dry, and the only discharge is to deeper aquifers.

In general, water quality in Texas and New Mexico decreases with depth. For example, the Rustler Formation water quality is generally poor; total dissolved solids range from $286 \mathrm{mg} / \mathrm{L}$ in Ward County to $157,000 \mathrm{mg} / \mathrm{L}$ in Winkler County. Chloride concentrations can be as high as $89,700 \mathrm{mg} / \mathrm{L}$ in Winkler County, Texas (Richey et al. 1985). Because of this poor water quality, water for public water supply, irrigation, industry, livestock, and rural domestic use is often obtained from overlying aquifers, such as the Santa Rosa Sandstone Formation in the Dockum 
and from the Cenozoic alluvium in the Delaware basin (including the Ogallala aquifer, if present). In the Texas panhandle area, similar observations have been made regarding groundwater quality (Bair 1987); i.e., total dissolved solids and the concentration of brine increase with depth. 



\section{Regulatory Considerations}

This section evaluates the major state and federal environmental requirements as they apply to disposal of NORM wastes in salt caverns. No attempt is made to encompass all types of permits, licenses, or approvals that must be obtained by an operator, including zoning approvals, mineral rights, and construction, safety, and fire code requirements.

\subsection{Hazardous Waste Status of NOW and NORM Waste}

The most important distinction between oil field wastes and many other types of industrial wastes is that the former are exempted from the hazardous waste requirements of the Resource Conservation and Recovery Act (RCRA). On July 6, 1988, the U.S. Environmental Protection Agency (EPA) issued a regulatory determination that exempted any wastes arising from the exploration, development, and production of crude oil, natural gas, and geothermal energy from regulation as hazardous wastes under RCRA Subtitle C (53 FR 25477). On March 22,1993 , the EPA clarified the 1988 determination and exempted many other wastes that were uniquely associated with exploration and production operations from RCRA Subtitle C requirements (58 FR 15284). Given the federal exemption from RCRA for oil field wastes, the waste management requirements faced by most operators will be state requirements.

The difference between NOW and NORM waste is the presence in the latter of radionuclides above a state-specified action level. The presence of those radionuclides does not change the waste's exempt status under RCRA as long as the waste itself, exclusive of the radiological components, is an exempt waste. Therefore, most oil field NORM waste is not hazardous waste.

The term "nonhazardous oil field waste" should not be interpreted to mean that no hazardous substances are found in oil field wastes. At least two oil- and gas-producing states, California and Louisiana, do not follow the blanket RCRA exemption for exploration and production wastes and associated wastes. In these states, each batch of waste is tested for specified parameters to determine. whether the waste is hazardous. Those wastes found to be hazardous must be managed at a hazardous waste management facility, which typically is much more expensive than management of a NOW disposal facility.

\subsection{Summary of NORM Regulations}

No existing federal regulations specifically address handling and disposal of NORM wastes. In the absence of federal regulations, individual states have taken responsibility for developing their own regulatory programs. These programs have been evolving rapidly over the last few years. Many states have promulgated NORM regulations, and many others are reviewing the magnitude of NORM issues within their borders and the need for specific regulations. 
The existing state regulatory programs establish requirements for (1) a NORM exemption standard or action level; (2) licensing of parties possessing, handling, or disposing of NORM waste; (3) the release of NORM-contaminated equipment and land; (4) worker protection; and (5) NORM waste disposal. The action level defining when waste must be managed as NORM varies from state to state. In general, state action levels range from 5 to 30 picocuries per gram (pCi/g) of total radium (i.e., radium-226 [Ra-226] plus radium-228 [Ra-228]). Several states have established two action levels, depending upon the radon emanation rate ${ }^{l}$ of the waste. In these states, the action level is $5 \mathrm{pCi} / \mathrm{g}$ total radium if the radon emanation rate exceeds $20 \mathrm{pCi}$ per square meter per second $\left(\mathrm{pCi} / \mathrm{m}^{2} / \mathrm{s}\right)$ and $30 \mathrm{pCi} / \mathrm{g}$ total radium if the radon emanation rate is below that level. A picocurie $(\mathrm{pCi})$ is equal to $10^{-12}$ curies $^{2}$.

Most state regulations currently approve the following disposal methods for waste exceeding the NORM action levels: (1) burial at either a licensed NORM waste or low-level radioactive waste disposal facility, (2) downhole disposal via encapsulation inside the casing of a plugged and abandoned well, and (3) underground injection into subsurface formations via a permitted Class II well. A few states also allow NORM waste to be disposed of via land spreading, provided that specific criteria are met. The State of Michigan also allows NORM waste containing up to $50 \mathrm{pCi} / \mathrm{g}$ radium to be disposed of in landfills that are permitted to accept only nonhazardous wastes (MDEQ 1996).

Downhole encapsulation and underground injection of NORM waste typically are approved on a case-by-case basis only and, in the case of underground injection, may require a modification to the existing Class II permit. In Texas, two commercial facilities have been permitted to receive and dispose of NORM waste via underground injection.

This report evaluates the regulatory aspects of salt cavern disposal of NORM waste in five states: Louisiana, Mississippi, New Mexico, Oklahoma, and Texas. Each of these states, except Oklahoma, has already enacted NORM regulatory programs and has expressed serious interest in disposal of NOW in salt caverns. Oklahoma currently is considering a draft set of NORM regulations. None of the NORM regulations promulgated or proposed in these five states specifically address the disposal of NORM waste in salt caverns. Each of these state programs, however, addresses the disposal of NORM waste into Class II injection wells, either directly or indirectly. The regulation of underground injection of NORM waste is relevant to the potential disposal of NORM waste in salt caverns because disposal into salt caverns is considered by most states to be equivalent to underground injection into Class II wells (Veil et al. 1996).

\footnotetext{
${ }^{1}$ The radon emanation rate is the fraction of radon atoms that escape the grain material containing the parent nuclide into the gaseous, porous space between the grains.

${ }^{2}$ A conventional unit, the curie (Ci) is defined as the quantity of a given radionuclide in which $3.7 \times 10^{10}$ atoms undergo nuclear transformations each second. One $\mathrm{Ci}$ is roughly equal to the decay rate of one gram of Ra-226.
} 


\subsubsection{Louisiana}

In Louisiana, the NORM regulations promulgated by the Louisiana Department of Environmental Quality (LDEQ) are contained in the Louisiana Administrative Code (LAC), Title 33, Part XV, Chapter 14, "Regulation and Licensing of Naturally Occurring Radioactive Material." The agency responsible for implementation of these regulations is the LDEQ Office of Air Quality and Radiation Protection, Radiation Protection Division. Under Section $1404(\mathrm{~A})(1)$ of these regulations, waste containing $\geq 5 \mathrm{pCi} / \mathrm{g} \mathrm{Ra}-226$ or Ra-228 above background must be managed as NORM waste.

In Section 1412(B), the regulations identify several forms of disposal as acceptable for NORM waste. Underground injection of NORM waste is not specifically identified in the regulations as an approved disposal option. However, Section 1412(B)(2) states that disposal of NORM waste by alternate methods is allowed, provided approval in writing is obtained from the Radiation Protection Division. Under this provision, underground injection may be allowed on a case-by-case basis in Class II injection wells. In addition, Sections 1412(B)(3) and (4) establish special provisions for the disposal of regulated NORM wastes at commercial NOW disposal facilities, including commercial Class II injection wells, regulated by the Louisiana Department of Natural Resources (LDNR.). In Louisiana, Class II injection wells are regulated and permitted by the LDNR Office of Conservation in accordance with Statewide Order No. 29-B (LAC 43:XIX).

Under this regulatory scenario, the disposal of NORM into either a commercial or noncommercial Class II well would require a specific license from the LDEQ and a Class II permit from the LDNR. To date, however, there has been only one instance in which NORM wastes have been disposed of in a noncommercial Class II well, and there have been no permitted disposals of NORM into a commercial Class II well (Talbot 1998).

With respect to the injection of NORM into salt caverns in Louisiana, the regulatory scenario is complicated by the existence of a statute specifically restricting the disposal of radioactive material into salt domes (Louisiana Revised Statute 30:2117). Part B of this statute states that "...no salt dome within the jurisdiction of the state of Louisiana shall be utilized as a temporary or permanent disposal site for radioactive waste or other radioactive material of any nature by any person." This statute, originally enacted in 1979, probably was not written with consideration to NORM disposal issues; however, NORM disposal in salt caverns probably would not be allowed in Louisiana without amendment to this statute.

\subsubsection{Mississippi}

In Mississippi, petroleum industry NORM waste is regulated by two agencies. The Department of Health has promulgated general NORM regulations under Part 801, Section N, of the Regulations for Control of Radiation in Mississippi. Under Section 801.N.4(a)(1), waste containing greater than $5 \mathrm{pCi} / \mathrm{g} \mathrm{Ra}-226$ or Ra-228 above background must be managed as 
NORM waste. The Mississippi State Oil and Gas Board has promulgated two rules specific to the disposal and control of petroleum industry wastes exceeding the Department of Health's action level defining NORM waste. Rule 68 of the Oil and Gas Board Statewide Rules and Regulations specifically addresses the disposal of NORM waste in wells that are about to be plugged and abandoned. Rule 69 establishes regulations for the control of NORM to ensure that radiation exposures to workers and the general public are minimized.

In Rule 68, Section IV.D, underground injection of NORM waste into a well about to be plugged and abandoned is identified as an allowable disposal method, provided specific limitations are met and approval is obtained from the Oil and Gas Board. Limitations contained in Section V of this rule address minimum depth below the base of the lowest underground source of drinking water, pressure test requirements, plugging requirements, and required well marker information. Any well in which NORM waste is injected must be permitted as a Class II injection well under Rule 63 of the Statewide Rules and Regulations, even though the well will subsequently be plugged and abandoned and not used again for underground injection.

Currently, there are no rules or regulations in Mississippi specifically addressing the disposal of NORM waste into active Class II injection wells. Section N.12(a) of the Health Department regulations lists several general standards for NORM waste disposal that are unrelated to underground injection. However, this section also provides for the disposal of NORM waste by alternate methods, provided approval is obtained from the Health Department. This language allows the state flexibility in addressing NORM waste disposal options such as underground injection into Class II wells. Because Class II wells are regulated by the State Oil and Gas Board under Rule 63, it is likely that the Oil and Gas Board would be the agency responsible for allowing or disallowing the disposal of NORM waste in Class II wells. This form of disposal could require modifications to Rule 63, or the promulgation of a new rule; however, to date, the Oil and Gas Board has not considered this issue (Ford 1998).

\subsubsection{New Mexico}

In New Mexico, the regulation of NORM waste has been divided between two agencies. The New Mexico Environment Department (NMED) regulates the possession, use, disposal, transfer, and storage of NORM waste under Title 20 of the New Mexico Administrative Code (NMAC), Chapter 3, Part I, Subpart 14. The New Mexico Oil Conservation Division (OCD) regulates the disposal of petroleum industry NORM waste under Title 19 NMAC, Chapter 15, Part I, Rule 714. Under Section 1403(A) of the NMED regulations, waste containing greater than $30 \mathrm{pCi} / \mathrm{g}$ Ra-226 above background must be managed as NORM waste.

Under Section 1407(B) of the NMED regulations, the disposal of NORM waste by deepwell injection is allowed, provided that a general license is obtained from the NMED and applicable rules established by the OCD are complied with. The OCD regulations specific to underground injection of NORM waste are contained in Rule 714, Section E. This section states that underground injection of NORM waste will be permitted in Class II wells on a case-by-case 
basis, provided that such injection is performed in a manner that is protective of the environment, public health, and fresh waters, and is in compliance with the OCD rules pertaining to injection. Despite these provisions, to date, the underground injection of regulated NORM waste has not occurred in New Mexico because there has been some disagreement between the OCD and the Rocky Mountain Low-Level Radioactive Waste Board (RMLLRWB) regarding which agency had regulatory authority over the management of NORM waste (Anderson 1998). On June 1, 1998, the RMLLRWB amended its Rule 1 to exclude from its authority the "placement or injection of oil and gas NORM in oil and gas wells in accordance with any applicable state regulations, as long as the oil and gas NORM is produced within the region and the wells are owned or operated by the person(s) who produced the oil and gas NORM." This amendment should allow future disposal of NORM via injection into Class II wells in New Mexico under the OCD rules in some cases.

A rule-making process is currently underway to address the development of regulations for the disposal in salt caverns of exploration and production waste not suitable for injection in Class II wells (e.g., sludges, tank bottoms, and other solid waste). Any proposals for the disposal of regulated NORM into salt caverns would go through a similar public, rule-making process. Such a process, however, could be quite controversial because salt cavern disposal of NORM waste could be construed to be related to the DOE's proposed WIPP near Carlsbad, New Mexico, which has been the target of significant levels of opposition within the state (Anderson 1998).

\subsubsection{Oklahoma}

The Oklahoma Department of Environmental Quality has drafted a set of NORM regulations that, if promulgated, will be contained in Title 252, Chapter 400, Subchapter 19 of the Oklahoma Administrative Code. Under Part 3 of these proposed rules, materials containing greater than $30 \mathrm{pCi} / \mathrm{g}$ of $\mathrm{Ra}-226$ or Ra-228 will need to be managed as NORM wastes. Under Part 11, owners and operators of Class I and Class II injection wells who are authorized under a general NORM permit will be allowed to dispose of NORM waste in these injection wells, provided the owner is in compliance with all applicable underground injection control rules and permit conditions, and that the sludges and scales to be injected are in the form of a pumpable slurry in which the entrained solids are so fine grained that they will not plug the injection formation.

In Oklahoma, Class II injection wells are regulated and permitted by the Oklahoma Corporation Commission (OCC) under Section 165 of the Oklahoma Administrative Code, Chapter 10, Subchapter 5 (165:10-5-1 through 15). Currently, these rules do not address injection of materials containing NORM. Rules promulgated by the Department of Environmental Quality regarding the disposal of regulated NORM in Class II wells would need to be integrated with existing OCC Class II regulations and permit requirements; this probably would require a formal rule-making process (Fiddler 1998). 


\subsubsection{Texas}

In Texas, the regulation of NORM waste has been divided among agencies. The Texas Department of Health regulates the possession, use, transfer, and storage of NORM waste under Part 46 of the Texas Regulations for Control of Radiation. The Texas Natural Resources Conservation Commission has jurisdiction over the disposal of non-oil-and-gas NORM wastes. The Railroad Commission of Texas (TRC) regulates the disposal of oil and gas waste contaminated with NORM under Title 16, Part I, Chapter 3, Rule 94 of the Texas Administrative Code (TAC). Under Section 46.4(a)(1)(i)(b), wastes containing concentrations less than or equal to $30 \mathrm{pCi} / \mathrm{g} \mathrm{Ra}-226$ or Ra-228 are exempt from the NORM regulations, provided that the radon emanation rate is less than $20 \mathrm{pCi} / \mathrm{m}^{2} / \mathrm{s}$. If the radon emanation rate exceeds this limit, the wastes are exempt only if the radium concentrations are less than or equal to $5 \mathrm{pCi} / \mathrm{g}$.

Under 16 TAC I.3.94(f), the regulation states that oil and gas NORM waste may bedisposed of via injection if a permit is obtained. The TRC will issue a permit provided the applicant demonstrates that the disposal will be conducted in a manner that is protective of public health, safety, and the environment. The permit will specify necessary construction and operating requirements. Currently, underground injection of NORM waste is occurring in Texas at two commercial facilities owned by Newpark Environmental Services, Inc. and Lotus LIC. To date, there has been only one instance of noncommercial injection of regulated NORM waste in Class II wells in Texas (Ginn 1998).

\subsection{Salt Caverns and the Underground Injection Control Program}

Veil et al. (1996) contains a detailed discussion of the Safe Drinking Water Act's (SDWA's) Underground Injection Control (UIC) program and how it relates to cavern disposal. The key elements are summarized below.

\subsubsection{Federal UIC Requirements}

Unlike most other methods for disposing of nonhazardous oil field waste, injection wells are subject to the requirements of the UIC program (see EPA regulations at 40 CFR 144-146). EPA's regulations define a well as a bored, drilled, or driven shaft, or a dug hole, whose depth is greater that the largest surface dimension. An injection well means a well into which fluids are being injected. All injection wells are assigned to one of five classes. Class II wells inject fluids that are brought to the surface in connection with natural gas storage operations or conventional oil or natural gas production. Injection wells for disposing of produced water are Class II wells. Likewise, salt caverns for disposing of NOW and NORM waste and the wells leading from the surface to the caverns are Class II wells. Throughout this report, the term "salt cavern" includes not only the actual cavern (injection zone portion) but also the wells used to inject materials into the caverns. 
Most types of NOW are brought to the surface with oil and gas production. However, it is not possible to claim that the primary types of NORM waste (i.e., sludge, scale, and contaminated soil) are brought to the surface in their final form. Although the chemical and radiological constituents of these wastes come from the subsurface, the wastes themselves are not formed until the fluids are at the surface. There has been some uncertainty among state regulatory agencies as to whether these wastes are eligible for injection into Class II wells. In February 1996, the Ground Water Protection Council asked the EPA to clarify that all exempted oil field wastes can be injected into Class II wells. In June 1996, the EPA responded to the request in a letter from Robert Blanco, Acting Director of EPA's Ground Water Protection Division (Blanco 1996). The letter does not provide further guidance, but rather concludes that the EPA trusts the judgement of states that administer their own UIC programs as to whether a particular waste meets the criteria for Class II fluids.

States seeking authority to administer the UIC program may obtain primacy in two ways. Under Section 1422 of the SDWA, states must demonstrate that their regulations are at least as stringent as those adopted by the EPA. To provide greater flexibility than what is allowed under the Section 1422 requirements for states administering Class II programs, Congress added Section 1425 to the SDWA, which requires states seeking delegation to have an underground injection program that meets the requirements of Section 1421(b)(1)(A)-(D) and that would be effective enough to prevent any underground injection that would endanger drinking water sources.

\subsubsection{State UIC Requirements}

Many of the oil- and gas-producing states have obtained the authority to administer the UIC program. Veil et al. (1996) summarize state UIC regulations and report on contacts with regulatory agencies in 11 oil-producing states where salt caverns exist to determine whether the state had any regulations that either authorized or prohibited cavern disposal. Of those states, only Texas had authorized any NOW disposal caverns, four of which are in operation. Texas has initiated a rule-making process for the development of regulations addressing the injection of NOW into salt caverns. This process has been sidetracked by two issues regarding the injection well rules - notice requirements and financial security requirements. When those two issues have been resolved, the state will move forward with the salt cavern disposal rules. New Mexico is presently developing NOW cavern disposal regulations. No other states are presently working on NOW or NORM cavern disposal regulations, although Louisiana and Mississippi have previously expressed serious interest in cavern disposal for NOW.

\subsection{Regulatory Barriers}

A review of federal UIC regulations and NORM and UIC regulations from the five states that have expressed some interest in cavern disposal indicated that there are no outright barriers 
or prohibitions against NORM disposal in salt caverns, except for Louisiana, which prohibits disposal of radioactive wastes or other radioactive materials in salt domes. Presently, however, only Texas and New Mexico are working on disposal cavern regulations, and no states have issued permits to allow cavern disposal of NORM waste. State regulatory agencies may need to revise their NORM waste management or UIC regulations to accommodate cavern disposal. These agencies may need time to further investigate the concept of NOW disposal in caverns before they are willing to develop regulations and issue permits authorizing NORM waste disposal in caverns. 


\section{Background on NORM}

\subsection{NORM Occurrence and Chemistry}

Oil and gas production and processing operations sometimes accumulate NORM at elevated concentrations in by-product waste streams. The sources of most of the radioactivity are isotopes of uranium-238 (U-238) and thorium-232 (Th-232) naturally present in subsurface formations from which oil and gas are produced. The primary radionuclides of concern in NORM wastes are Ra-226 of the U-238 decay series, and Ra- 228 of the Th-232 decay series. Other radionuclides of concern include radionuclides that form from the decay of Ra-226 and Ra-228; these decay progeny are shown in Figures 4 and 5, which depict the decay chains for U238 and Th-232, respectively.

The production waste streams most likely to be contaminated by elevated radium concentrations include produced water, scale, and sludge (Smith et al. 1996). Spills or intentional releases of these waste streams to the ground can result in NORM-contaminated soils that must also be disposed of. Radium, which is slightly soluble, can be mobilized in the liquid phases of a formation and transported to the surface in the produced water stream. Dissolved radium either remains in solution in the produced water or precipitates out in scales or sludges. Conditions that appear to affect radium solubility and precipitation include water chemistry (primarily salinity), temperature, and pressure.

NORM contamination of scale and sludge can occur when dissolved radium coprecipitates with other alkaline earth elements such as barium, strontium, or calcium. In the case of scale, the radium coprecipitates, primarily with barium, to form hard, insoluble sulfate deposits. Scale typically forms on the inside of piping, filters, injection wellhead equipment, and other water handling equipment, but also can form as a coating on produced sand grains. In the case of sludge, radium can be present in several forms. It can coprecipitate with silicates and carbonates that form in the sludge, or it can be present in pieces of barium sulfate scale that become incorporated into the sludge. NORM-contaminated sludges can accumulate inside piping, separators, heater/treaters, storage tanks, and any other equipment where produced water is handled. The EPA estimates that approximately 25,000 tons of NORM-contaminated scale and 225,000 tons of NORM-contaminated sludge are generated annually by the petroleum industry (EPA 1993).

In addition to their radioactive characteristics, NORM wastes also have physical and chemical characteristics typical of NOW. Tomasko et al (1997) assumed that a typical NOW stream going to a disposal cavern consists of accumulated heavy hydrocarbons, paraffins, inorganic solids, and heavy emulsions. 


\subsection{NORM Management Practices}

The presence of NORM in oil and gas wastes has been recognized since the 1930s. NORM was not recognized as a waste management issue, however, until the mid-1980s, when the industry and regulators realized that NORM occurrence was more widespread than originally thought and that activity levels could be high. The petroleum industry adopted methods for managing and disposing of NORM-contaminated wastes that are more restrictive than past practices and are likely to provide greater isolation of the radioactivity. Simultaneously, state agencies have promulgated NORM regulations that establish new, more restrictive standards for the management and disposal of NORM wastes. These actions have served to limit the number of available disposal options for NORM wastes, thereby increasing waste management costs.

The largest volume oil and gas waste stream that contains NORM is produced water. Except at offshore platforms, which discharge produced water to the ocean, nearly all produced water is injected into the subsurface through injection wells. At this time, the radium content of produced water going to injection wells is not regulated. Consequently, radium that stays in solution in the produced water stream does not present a significant waste management problem from a regulatory perspective and is not considered further in this study.

Some operators dispose of NORM wastes at their own sites although, most use off-site commercial disposal facilities. Pipes and casing with NORM contamination may be recycled as scrap steel if NORM levels are below background concentrations. In the past, NORM was commercially managed by surface treatment, through which NORM was blended with nonradioactive materials to reduce the NORM activity below action levels and to spread on the land. Today, the primary method used for disposal of NORM wastes is underground injection. Smaller quantities of NORM waste are disposed of at licensed radioactive waste landfills, encapsulated in the casing of a well being abandoned, or managed on lease sites through land spreading.

Only four off-site commercial NORM disposal companies have been identified in the United States; two of these inject the NORM waste underground and the other two bury NORM. waste in landfills. Identification of disposal companies by name in the following sections does not constitute an endorsement of those companies or provide any indication of their performance capabilities. The companies are included solely to provide an indication of the types of commercial disposal options available to operators in the early 1998 time frame.

\subsubsection{Underground Injection}

NORM-contaminated scales, sludges, and other solid wastes have also been disposed of through underground injection wells. McArthur et al. (1995) report on a NORM waste injection project in the North Slope Alaska oil field developed by two major producing companies. Approximately 100 tons of NORM solids were cleaned from 3,000 oil production pipes and 
casing. The resulting solids were processed to a particle size of less than 80 micrometers $(\mu \mathrm{m})$, slurried with $10,000 \mathrm{bbl}$ of water, and then injected into a Class II injection well.

Two of the four U.S. commercial NORM disposal companies utilize underground injection. Newpark Environmental Services, Inc., operates a NORM disposal facility near Winnie in eastern Texas that receives the majority of all NORM wastes disposed of commercially in the United States. In July 1997, Lotus, LLC opened a NORM disposal facility in western Texas near Andrews. Both facilities crush, mill, and slurry the incoming NORM waste before injecting it.

DOE has funded BPF, Inc., to develop a mobile NORM treatment system. The BPF process dissolves the radioactive component of NORM into an aqueous solution that can then be disposed of through underground injection. The residual solids no longer contain radioactivity above levels of regulatory concern and can be disposed of as NOW (Capone et al. 1997). As of summer 1998, the BPF process is at the pilot-scale stage of development.

Other disposal contractors (e.g., Apollo Services and National Injection Services) will come to an operator's site and process NORM wastes so that they can be injected through the operator's own injection well. The process consists of grinding and milling the waste to a small particle size, slurrying the waste to facilitate pumping, and injecting to formations at fracture pressure (Sipple-Srinivasan et al. 1997). Apollo Services and National Injection Services are primarily disposing of drilling wastes at offshore platforms, but can also accommodate NORM wastes.

\subsubsection{Landfill Disposal}

The other off-site commercial NORM waste disposal option in the United States is burial in landfills. US Ecology operates a low-level radioactive waste landfill on DOE's Hanford site in southeastern Washington State. The landfill is primarily designed to handle radioactive wastes other than oil field wastes, but oil field NORM waste is accepted. Because of its location remote from most oil-producing areas and the higher costs associated with general low-level radioactive waste management requirements, US Ecology receives relatively little NORM waste. For example, in 1997, US Ecology received less than $500 \mathrm{ft}^{3}$ of NORM wastes.

Envirocare of Utah, Inc., also operates a landfill for mixed wastes and low-specific activity radioactive wastes in Clive, Utah, that has accepted NORM waste for disposal.

\subsubsection{Encapsulation and Downhole Disposal}

Under the encapsulation and downhole disposal option, an operator encapsulates NORM waste either inside a section of pipe that is then sealed on both ends and lowered into a wellbore or directly in the wellbore. A plug is placed on top of the waste-containing zone. Scaife et al. (1994) report on two encapsulation projects conducted in the offshore Gulf of Mexico. In the 
first project, NORM waste was placed into eight joints of casing as the pipe was being lowered into the hole. In the second project, 31 drums of NORM waste were placed into 21 joints of casing on shore and sealed on both ends. The sealed joints were transported offshore and lowered into the well bore. In both projects, cement plugs were placed on top of the wastecontaining joints.

Encapsulation works well for NORM waste disposal, but each well can handle only a relatively small volume of waste. Because of this restriction, the process is not widely used.

\subsubsection{Land Spreading}

The principle behind land spreading is to mix NORM wastes having an activity concentration higher than the action level with clean soil so that the resulting blend has an activity concentration lower than the action level. Sanifill/Campbell Wells operated a commercial land spreading site until recently, when it no longer was economical to operate. Some producers utilize land spreading on their lease site to blend patches of high-activity NORM soils with low-activity NORM soils. However, the present use of land spreading for disposal of NORM waste is limited. 


\section{Technical Feasibility of NORM Waste Disposal in Salt Caverns}

The main purpose of this report is to evaluate various aspects of NORM waste disposal in salt caverns. The first question to answer is whether cavern disposal is technically feasible for NORM waste (exclusive of produced water, which is disposed of primarily through injection wells) given the current state of technology. The answer is clearly yes. NORM waste is physically and chemically similar to NOW. Its primary difference from NOW is the presence of radionuclides. The presence of radionuclides may require additional safety precautions when handling the NORM waste, but the actual disposal would be no different from NOW. NOW waste is currently being disposed of in four U.S. salt caverns and in several Canadian caverns without technical difficulties. There is no technical reason why these caverns or other future disposal caverns could not accept NORM waste equally well. 



\section{Cost of NORM Waste Disposal}

\subsection{Elements of Cost}

The total cost of NORM waste disposal comprises several cost components. In addition to the disposal cost, operators must consider costs associated with transportation, physical inspection, radionuclide and chemical analysis, and container decontamination. Given the limited number of off-site commercial disposal sites available, transportation costs from remote locations can represent a significant component of total cost. Operators must consider all cost components before selecting a disposal option. To the extent possible, it will be indicated whether the cost figures presented in this chapter reflect just the cost of disposal or also include other costs.

In addition to direct costs, there are other important potential costs, such as long-term liability under the Superfund law. Remediation costs, if the disposal activity results in environmental contamination, can be substantial. The EPA estimates the average cost for cleaning up a Superfund site is approximately $\$ 30$ million in 1994 dollars (60 FR 20330, April $25,1995)$. Long-term liability costs are not quantified here because they represent a future potential cost, not an actual current cost. Liability insurance rates paid by operators include the insurer's perception of long-term liability from all phases of the operator's business, including waste disposal. The incremental insurance costs associated with NORM waste disposal were not identified in this study.

\subsection{Historical NORM Waste Disposal Costs}

The API surveyed the U.S. oil and gas industry in 1992 to learn how NORM waste was disposed of, how much it cost for disposal, and what volume of NORM required disposal (API 1996). The results of that survey indicated that disposal costs varied greatly, depending on the specific activity of the NORM, the number of drums being disposed of, and the disposal option selected. Disposal costs from API (1996) are summarized in Table 1. The costs ranged from $\$ 49$ to $\$ 3,333$ per 55 -gal drum, with an average of $\$ 544$ per drum (equivalent to $\$ 415$ per 42 -gal $\mathrm{bbl})$. For some of the disposal options, various additional costs are identified, including radiological analysis $(\$ 100-\$ 500$ per sample), chemical analysis $(\$ 250-\$ 500$ per sample), transportation ( $\$ 6$ - $\$ 40$ per drum), "pretreatment washing volume reduction" $(\$ 10-\$ 25$ per drum), permitting and manifesting, administrative costs, and non-NORM waste disposal costs.

\subsection{Current NORM Waste Disposal Costs}

The costs presented in the previous section are costs that operators faced in 1992. Some of the disposal options available in 1992 are no longer available, particularly the commercial surface treatment facility in Louisiana. That facility is currently going through closure because the operation is no longer profitable. 
In general, NORM waste disposal costs have decreased between 1992 and 1998. The following sections provide current information on the cost of off-site commercial disposal companies and other companies that provide disposal services at an operator's site using an existing injection well. These costs are summarized in Table 2. Cost information was collected directly from disposal companies and from oil and gas operators.

\subsubsection{Costs for Off-site Commercial Disposal of NORM Waste}

The costs presented below are those reported to the authors in early 1998. They are included in this report for comparative purposes at one point in time. There is no guarantee that these costs reflect the actual costs that would be charged to customers or that these companies still charge the same fees. Most commercial disposal companies will negotiate more favorable rates than those described below for customers with large volumes of waste.

Newpark Environmental Services, Inc., charges $\$ 196.50$ per 55-gal drum or $\$ 150 / \mathrm{bbl}$ for disposal of NORM wastes through injection. This cost includes inspection and verification of contents as well as the necessary analytical costs. The cost of decontamination is $\$ 25$ for a drum and $\$ 150$ for a bulk container (Sammons 1998). Transportation costs are not included in these figures.

Lotus LLC began accepting NORM waste in 1997. Lotus charges $\$ 132$ per 55 -gal drum and $\$ 100 / \mathrm{bbl}$ for disposal by injection. Gamma spectroscopy analysis costs an additional $\$ 100$ per sample. Transportation cost is not included but is estimated to be about $\$ 3$ per loaded mile for a full 72-bbl roll off box (Kelly 1998).

US Ecology operates a low-level radioactive waste disposal landfill that receives various types of radioactive waste, including NORM waste. Because the facility primarily receives radioactive wastes other than oil field wastes, the requirements are more stringent and costs are higher. Base disposal costs range from $\$ 500$ to $\$ 550$ per 55 -gal drum or from $\$ 66.67$ to $\$ 73.33$ per cubic foot, depending on the volume. The State of Washington does not recognize the RCRA exemption from hazardous waste status for exploration and production wastes. Therefore, each waste stream must be analyzed for hazardous waste characteristics and radionuclides. Transportation cost is not included but is estimated to be about $\$ 2.10$ per mile based on a full truck load. All waste generators shipping waste to US Ecology must obtain a site use permit from the Washington Department of Ecology. Obtaining the site use permit will add to the total cost. All shipments are subject to a minimum disposal charge of $\$ 2,500$ (White 1998).

Envirocare of Utah, Inc. operates a landfill for mixed wastes and low-specific activity radioactive wastes that has, on occasion, accepted NORM waste for disposal. Envirocare declined to provide a standard price for disposal but indicated that it set prices on a case-by-case basis. According to the company contact, Envirocare is competitive when bidding on large disposal jobs but is not competitive on small jobs because its overhead costs, set for all low-level 
radioactive waste disposal activities, is quite high and is constant regardless of the job size. For large jobs, the overhead is spread over many drums of waste and is therefore low on a cost per drum basis (Rafati 1998).

\subsubsection{Costs for On-site Commercial Disposal of NORM Waste}

The four companies discussed in this section process and dispose of NORM waste onsite. All four companies use the operator's injection well to dispose of the NORM wastes.

$\mathrm{BPF}$, Inc., is developing a system that dissolves the radioactive component of NORM into an aqueous solution that can then be disposed of through underground injection. The residual solids no longer contain radioactivity above levels of regulatory concern and can be disposed of as NOW. The process is currently at the pilot stage of development. BPF estimates that costs of the full-scale system, when commercially available, will be approximately $\$ 140 / \mathrm{bbl}$ $\pm 20 \%$. These costs would include an initial survey, obtaining the necessary permits, labor, offsite disposal costs for the resulting NOW solids, chemicals, and a final survey. The cost of an injection well is not included if the operator does not already have a functioning injection well (Bush 1998).

At least two companies, Apollo Services and National Injection Services, provide NOW and NORM disposal at an operator's site. Wastes are ground up, slurried, and injected into the operator's own injection well. The process of injecting ground and slurried NORM waste could potentially plug the receiving formation. Operators should consider the potential cost of an injection well workover when estimating total disposal costs for these companies.

As of early 1998, Apollo was primarily disposing of NORM at offshore platforms. Apollo estimates that NORM waste disposal costs range from $\$ 100 / \mathrm{bbl}$ to $\$ 300 / \mathrm{bbl}$, depending on the volume of NORM to be disposed of (Reddoch 1998).

National Injection Services disposes of NOW and NORM through on-site injection. National's cost ranges from $\$ 15 / \mathrm{bbl}$ to $\$ 150 / \mathrm{bbl}$, depending on the nature of the materials to be disposed of (Page and Guidry 1999).

\subsection{Actual Disposal Practices and Costs}

To provide another perspective on NORM waste disposal, several major U.S. oil and gas producers were asked how they dispose of their NORM wastes. Contact persons at these companies agreed to provide information under the condition that their companies not be identified by name. Therefore, companies are identified as Company A, Company B, etc.

Company A disposes of about $600 \mathrm{bbl} /$ year of NORM waste from offshore and the eastern United States. at a commercial injection well facility. The cost for disposal and 
decontamination of containers is $\$ 150 / \mathrm{bbl}$, and the cost for lab analyses, transportation, and handling added another $\$ 30 / \mathrm{bbl}$.

Company B used to operate its own offshore injection well for disposing of offshore NORM waste but now sends all of its NORM wastes to a commercial injection well facility. Disposal costs range from $\$ 125 / \mathrm{bbl}$ to $\$ 200 / \mathrm{bbl}$. The typical cost rate for a 15 -barrel cuttings box is $\$ 150 / \mathrm{bbl}$. Company B does some analytical work before shipping at a cost of $\$ 100 /$ test. Transportation costs are estimated to be $\$ 25 / \mathrm{bbl}$.

Company $\mathrm{C}$ sends much of its NORM waste to a commercial injection well facility. In the past, Company $\mathrm{C}$ operated annular injection wells offshore for NORM disposal. Disposal costs at these wells ranged from $\$ 500 / \mathrm{bbl}$ for "trouble-free" projects to more than $\$ 2,000 / \mathrm{bbl}$ for "trouble-plagued" projects. As less expensive commercial alternatives became available, Company $\mathrm{C}$ opted for off-site commercial disposal. Company $\mathrm{C}$ needs to dispose of a large volume of NORM-contaminated soils from remediation projects and recently opted to develop its own onshore injection well to handle these wastes. Cost figures are not yet available, but the contact person noted that capital and operating costs are high. In order to make the process cost effective on a $\$ / \mathrm{bbl}$ basis, the project needs to handle a large volume of wastes.

Company D also sends most of its NORM waste to a commercial injection well facility. During lease abandonment, Company D sometimes blends patches of NORM-contaminated soils with clean soils to reduce the aggregate NORM activity below levels of regulatory concern. In other cases, large volumes of NORM-contaminated soils are excavated and sent off-site for disposal. Company D did not provide specific cost figures but indicated that it had received a significant discount from the disposal company's standard rates for one particularly large project.

Two companies operating in Alaska utilize different NORM disposal methods. Company E ships all its Alaskan NORM waste to the Newpark facility in Texas, whereas Company F grinds and slurries NORM waste and injects it into the company's own injection well. No cost information is available for these projects.

One disposal option that was not mentioned by any of the companies is encapsulation in pipes and casing and downhole disposal during plugging and abandonment. This practice is probably occurring, but the costs tend to be higher than other options (see Table 1). If a company has NORM waste at the same location where it is plugging and abandoning multiple wells, this option may be cost effective.

\subsection{Prospects for Cost-Effective NORM Waste Disposal in Salt Caverns}

The preceding sections describe the range of costs for disposal of NORM waste. The majority of all NORM wastes sent off-site for disposal are presently going to Newpark's facility. Newpark's disposal cost is about $\$ 150 / \mathrm{bbl}$. The Lotus facility charges about $\$ 100 / \mathrm{bbl}$. These 
are the cost targets that a salt cavern disposal facility would need to meet or beat to be cost competitive.

Long-term liability costs are an important consideration for major operators. Under the Comprehensive Environmental Response, Compensation, and Liability Act (CERCLA), companies that dispose of wastes into sites that later become Superfund sites have joint and several liability. This means that a company that contributes only a small portion of a disposal site's waste volume can potentially be held liable for a large portion of the remediation costs if some or all of the other waste contributors are out of business or are otherwise unable to pay. Given that background, prudent companies that have historically disposed of waste at a particular disposal site will think twice before extending their potential liability to new disposal sites, even if the new disposal sites are less costly. Any new disposal cavern company will have to overcome not only long-term liability concerns of potential customers, but also the customers' lack of familiarity with a new disposal technology.

One way to win customers is to offer lower costs. Operators of the four permitted disposal caverns in Texas were contacted to see whether they had made any cost estimates of what they might charge customers if they were authorized to accept NORM wastes. They currently charge from $\$ 1.95 / \mathrm{bbl}$ to $\$ 6 / \mathrm{bbl}$ for NOW wastes. To be authorized to dispose of NORM wastes, cavern operators would need to upgrade their aboveground waste handling facilities and analytical capabilities, among other things. Although none of the cavern operators had even preliminary cost estimates, one cavern operator felt that it could realistically operate at costs below $\$ 150 / \mathrm{bbl}$, Newpark's cost. He also noted that if regulatory agencies allow NORM disposal in caverns, competition will drive the price lower (Moore 1998).

NOW disposal caverns have shown that they are cost competitive with other NOW disposal facilities in the same geographic area (Veil 1997). This study does not constitute a formal market analysis, and the costs to upgrade a cavern disposal operation for NOW to one that disposes of NORM waste have not been quantified. Nevertheless, there is a reasonable chance that NORM waste disposal caverns would be able to compete economically with existing off-site commercial NORM disposal facilities once regulatory agencies allow the practice to occur. 



\section{Risks from Disposal of NORM Waste in Salt Caverns}

Tomasko et al. (1997) provide a detailed description of the assumptions and calculations used to estimate the human health risk of NOW disposed of in salt caverns. To the extent possible, the risk estimates in this report for disposing of NORM waste in salt caverns follow the same set of assumptions and calculations. NORM waste still has similar chemical properties to NOW, but also has radioactive properties that may increase the risk. The risk calculations for NOW are not repeated in detail here; NORM risk calculations are described.

\subsection{Contaminants of Potential Concern}

Contaminants of potential concern at a site are those that may be hazardous to human health and/or the environment under current or future site conditions. Identifying the contaminants of potential concern helps focus the risk assessment on those contaminants that may be of potential significance to human health. This study does not address potential ecological risks. However, they are likely to be low, because under most release scenarios, cavern fluids are released to groundwater not surface water.

As the risk assessment is conducted, it may be determined that the risks associated with some potential contaminants are insignificant and can be dropped from further consideration. For example, the susceptibility of some potential contaminants to transport through environmental media may be insufficient to allow them to come in contact with humans. In such cases, the contaminant need not be considered further in the risk assessment.

Tomasko et al. (1997) identified contaminants of potential concern in NOW on the basis of information presented in EPA's 1987 Report to Congress (EPA 1987) and a later draft pertaining to Selected Associated Wastes (EPA 1994). The chemical contaminants in the NOW include benzene, lead, arsenic, cadmium, chromium, and boron. After further evaluation of the physical and chemical properties of lead and boron that would serve to minimize their availability to be transported, Tomasko et al. (1997) dropped these two contaminants from further consideration.

The primary radioactive contaminants of potential concern in NORM include Ra-226, $\mathrm{Ra}-228$, and their decay progeny (see Figures 4 and 5, respectively). Ra-226 is brought to the surface in the dissolved phase, and then it precipitates out into scale or sludge. Ra-226 has a half-life of 1,600 years and decays directly to Rn-222 (half-life of 3.8 days) through alpha and gamma emission. $\mathrm{Rn}-222$ and its first four decay progeny have relatively short half-lives and will reach secular equilibrium ${ }^{3}$ with the Ra-226 parent in approximately one month. The

${ }^{3}$ Secular equilibrium refers to the stable relationship established in nature between a radioactive element that has a long half-life and a decay product that has a much shorter half-life. For example, Ra-226 has a half-life of about 1,600 years. As this element decays and emits radiation, $\mathrm{Rn}-222$, which has a half-life of about 3.8 days, is produced. Over time (after seven progeny half-lives), an equilibrium is established between the concentration of 
remaining radioactive progeny - lead-210 ( $\mathrm{Pb}-210)$, bismuth-210 (Bi-210), and polonium-210 (Po-210) - will eventually reach secular equilibrium with Ra-226 after approximately 150 years because of the longer half-life of $\mathrm{Pb}-210$ (22 years).

Ra-228 has a half-life of 5.8 years. The first progeny of Ra-228 is actinium-228 (Ac-228), which has a short (6.1 hours) half-life, thus yielding rapid ingrowth to secular equilibrium (approximately two days). The Ac-228 isotope decays by beta and gamma emission to Th-228, which has a half-life of 1.9 years. The Th-228 radioactive progeny all have much shorter half-lives than the Th-228 parent, thus resulting in secular equilibrium within one month. Similarly, Th-228 will reach transient equilibrium with the original Ra-228 isotope after approximately five years.

\subsection{Contaminant Concentrations at the Time of the Release}

In the event of a release, some of the brine overlying the waste would leave the cavern. This brine would contain dissolved contaminants of potential concern. No data are available to show the chemical or radiological characteristics of the cavern brine at the time of release, because no disposal cavern has yet been closed. For the radiological contaminants, the total radium activity in the cavern is assumed to be $2,000 \mathrm{pCi} / \mathrm{L}$ in order to be consistent with previous studies (e.g., Smith et al. 1996). A cavern approved for NORM disposal may very well also be authorized to accept NOW; in such a case, the total cavern contents would only contain a small proportion of NORM. As a conservative measure, however, this study assumes that the entire cavern contents would be NORM waste and that any brine released from the cavern would contain $2,000 \mathrm{pCi} / \mathrm{L}$ of radium. Although definitive data describing the concentration ratio of $\mathrm{Ra}$ 226 to Ra-228 is not available, a ratio of 3:1 was used in this study based on Smith et al. (1996). Under these conditions, the Ra-226 activity would be $1,500 \mathrm{pCi} / \mathrm{L}$, and the $\mathrm{Ra}-228$ activity would be $500 \mathrm{pCi} / \mathrm{L}$. In addition, the initial activity of any short-lived progeny was obtained by assuming that the daughters are in secular equilibrium (i.e., their activities would be the same as those of the parents).

\subsection{Fate and Transport for Contaminants of Potential Concern}

This study analyzes the health risk to humans at a receptor site. That receptor site is assumed to be a drinking water well located $1,000 \mathrm{ft}$ from the cavern in a horizontal direction. For completeness, two well completion depths are considered: (a) a shallow completion in a surficial aquifer (at a depth of $50 \mathrm{ft}$ ) and (b) a well completed at the depth of the salt cavern $(1,000 \mathrm{ft})$. For the postulated release scenarios described in Section 8.4.1, brine containing NOW and NORM waste would be discharged from the cavern and enter the surrounding rock or aquifer. The brine and its contaminants would then be transported laterally to the location of the

these two elements such that the activity of each element is equal. 
receptor well, where they would be pumped to the ground surface. Because of low-permeability layers, no significant vertical migration would occur for releases at the depth of the cavern.

Groundwater flow velocities are typically very slow, so that the time for transport of the contaminants to the receptor site is many years. The chemical and radiological characteristics of the brine after it has reached the receptor site would be different from those at the time of the release because physical, chemical, biological, and radiological processes would modify the brine during the long transit to the receptor site. One example of this that was used by Tomasko et al. (1997) is the retardation coefficient. As a contaminant plume moves away from the cavern release site, some fraction of each contaminant adsorbs onto solid surfaces and effectively retards the velocity of that contaminant's movement. The higher the retardation coefficient, the slower the contaminant migrates.

For radionuclides, initial activities would be reduced over time by radioactive decay, in addition to retardation. Because of large retardation coefficients and/or short half-lives, all of the potential radiological contaminants of concern mentioned in Section 8.1, except for Ra-226 and its decay progeny $\mathrm{Rn}-222$, have been eliminated from the risk analysis. These contaminants of concern are the same as those discussed by Smith et al. (1996) for subsurface disposal. Details on the fate and transport of Ra-226 and $\mathrm{Rn}-222$ are provided below.

The interaction of radium with geological materials and soils is highly variable. Distribution coefficients (mass of solute sorbed on solid surfaces per solid mass divided by the mass of solute per volume of solute [Freeze and Cherry 1979]) range from about $50 \mathrm{~mL} / \mathrm{g}$ to about $1,000 \mathrm{~mL} / \mathrm{g}$ (Sheppard et al. 1984). Within the $\mathrm{pH}$ range of 4 to 8 , radium does not readily form chemical complexes and readily coprecipitates with barium sulfate, carbonates, and ferric hydroxides. To produce conservative results, this study assumed a distribution coefficient of 50 $\mathrm{mL} / \mathrm{g}$. Assuming a bulk density of $1.7 \mathrm{~g} / \mathrm{cm}^{3}$ and a porosity of 0.1 for the rock through which the released fluids would travel, [to be compatible with Tomasko et al. (1997)], the retardation coefficient for radium would be about 850 . Sorption of radium onto a solid surface produces a retardation of radium's transport velocity in groundwater; that is, the velocity of the center of mass of a contaminant plume of radium will move at a retarded velocity of $V / R$, where $V$ is the velocity of groundwater and $\mathrm{R}$ is a retardation coefficient. For this value of retardation, the velocity of the center of the mass of radium would be 850 times less than that of the groundwater (Freeze and Cherry 1979). In 1,000 years, radium would travel about $12 \mathrm{ft}$ considering a groundwater velocity of $10 \mathrm{ft} /$ year.

The radioactive decay of Ra-226 produces $\mathrm{Rn}-222$ along the flow path between the point of release and the receptor site. Under saturated groundwater conditions, Rn-222 will be in the aqueous phase. If exposed to air, Rn-222 will leave the liquid phase and become a gas (Graves 1989). Because Rn-222 is a noble gas, it will have an inert behavior while in groundwater (Tanner 1964; Sanford et al. 1996) and its distribution coefficient will be essentially zero. It will not undergo significant retardation, and its center of mass will move at about the velocity of the groundwater. Its retardation coefficient is therefore assumed to be 1.0. Even 
though $\mathrm{Rn}-222$ will move much faster than its parent ( $\mathrm{Ra}-226)$, as it moves away from the Ra226 parent, its short half-life quickly reduces its concentration, and high concentrations of radon will occur only in the immediate vicinity of the parent.

\subsection{Exposure Assessment}

This section provides information needed to estimate the intake of NORM contaminants that increase human health risks. In this study, exposed individuals are expected to be those drinking groundwater contaminated by releases of NORM constituents from salt caverns containing NORM wastes. The exposure pathway would consist of release from the cavern (or casing or seal), transport through groundwater, and human exposure through ingestion of the contaminated groundwater. Potential exposure from inhalation of Rn-222 and its decay products from groundwater use inside a house was also evaluated. This section describes the scenarios and mechanisms that could lead to human exposure to NORM constituents and estimates radiological doses and human health risk to a potential receptor.

Once the cavern was full of waste, it would be sealed and abandoned. At the time of sealing, the cavern would be mostly filled with solids and semisolids that were not fully compacted. Brine would remain between the top of the cavern and the top of the waste mass. The pressure in the cavern would increase because of the combined effects of the addition of sensible heat from the surrounding salt and salt creep. Under these conditions, any breach of the cavern integrity would result in a release of some of the brine that contains soluble chemical and radiological contaminants from the waste. The solid wastes, however, would remain in the cavern.

When risks to the public from disposing of NORM waste in caverns are being assessed, potential release modes must be determined. Currently, little information exists on accidents for cavern disposal systems because there are only a few disposal caverns in operation and they have been operating for only a few years. However, what little accident information exists from disposal and storage caverns indicates that the caverns are safe and that the only accidents that have occurred were associated with surface facilities. Because insufficient information exists to quantify release probabilities for cavern disposal, results from the LPG storage industry and the SPR are used in this study as a basis for identifying potential release scenarios.

Although LPG industries and the SPR have a long history of safe operations, a statistically meaningful database for risk analysis is absent. To overcome this difficulty, a subjective, semiquantitative methodology was developed by Radian Corporation to evaluate risks for the LPG industry (Radian Corporation 1995). This methodology, developed by a panel of experts in the field of salt-cavern conversion for LPG storage, was based on a modified-Delphi approach (Brown and Helmer 1964) in which variability of the estimated parameters is reduced through group interaction. The Radian study identified 22 accident scenarios that could lead to releases to the environment. These accident scenarios can be grouped into three general categories: 
(1) cavern development and conversion, (2) cavern filling, and (3) post-closure releases. For this NORM waste disposal study, impacts were analyzed only for post-closure releases. Impacts from the first two scenarios are better addressed in a second tier assessment, in which sitespecific information would be used and more detailed design parameters would be defined.

Five release scenarios, based on the Radian findings, are discussed in this section: (1) inadvertent intrusion, which could produce a release of cavern fluid to the ground surface; (2) failure of the cavern seal, which could release contaminated fluid to the groundwater (the release could be either at the depth of the cavern or at more shallow depths); (3) release of contaminated fluid through cavern cracks; (4) release of contaminated fluid through leaky interbeds or nonhomogeneous zones of higher permeability material; and (5) a partial cavern roof fall, which could release contaminated fluid to deep or shallow groundwater, depending on the condition of the cavern seal. A discussion of each scenario is provided below.

\subsubsection{Cavern Release Scenarios}

\subsubsection{Inadvertent Intrusion}

In the inadvertent intrusion scenario, an exploratory well for oil or minerals penetrates a hypothetical waste disposal cavern that has a volume of one million $\mathrm{ft}^{3}$ (about 7.5 million gal). If the cavern contains $750,000 \mathrm{ft}^{3}$ of waste when full, approximately 2 million gal of brine lies above the waste. Groundwater wells probably would not reach the cavern because drinking or irrigation water could be obtained at shallower depths, and groundwater at the depth of the cavern would probably not be potable because of brine. Tomasko et al. (1997) estimate that a maximum of about 2,000 gal of contaminated fluid would flow from the cavern toward the surface. This value is about $0.1 \%$ of the fluid present in the cavern. In addition to brine and dissolved waste constituents, drilling muds and other associated fluids would also flow toward the surface.

If the blowout-protection system of the well failed, fluids from the cavern could spill onto the ground surface and form a pool in the vicinity of the well pad or be discharged into a lined pond. If the discharge occurred directly to the ground and the local topography was depressed, a small surface pond would form. If the pond had a radius of $25 \mathrm{ft}$, the depth of the spill would be about 1 in. without considering evaporative losses. For a spill this small, fluids from the cavern would not reach the underlying unconfined aquifer that occurs at a median depth of $20 \mathrm{ft}$, but would form a contaminated zone in the unsaturated soil. If the porosity of the soil was 0.3

4 This volume was selected to be consistent with Tomasko et al. (1997). The actual disposal caverns in Texas are somewhat larger, but are of the same order of magnitude. Hydrocarbon storage caverns, such as those used in the SPR, are much larger. For example, the only Texas disposal cavern located in domal salt has a volume of about 18 million gal. The volume of fluids likely to escape from larger caverns would be proportionately larger than those calculated here, but are estimated to be of the same order of magnitude. 
(Freeze and Cherry 1979), a mass-conservation calculation shows that the penetration depth of the fluids from the cavern would be less than $6 \mathrm{in}$. Mobilization of contaminants out of the contaminated zone could then occur by leaching. However, remediation activities at the site (e.g., removal of contaminated soil) would occur before the contaminants could dissolve and be transported by advection and dispersion to the water table.

This scenario is unlikely to occur, however. When issuing underground injection permits, agencies typically request an area of review that identifies active and inactive wells within a certain radius of the proposed well. Disposal caverns should be identified during the area of review. If an inadvertent intrusion still occurs, it would last for a short time and the pond water would be very unappetizing (i.e., the water would have a very high turbidity because of the drilling mud, it would be very salty [saturated brine], it would be oily because of the presence of organic materials, and it would probably have an unpleasant odor). Because the volume of released fluid for this scenario would be small, the effects would be of very short duration, the liquid would not be potable, and such a spill would be quickly remediated, this scenario was eliminated from further analysis.

\subsubsection{Release through the Cavern Seal}

For this scenario, the pressure in the cavern is assumed to become sufficiently high that the cavern seal fails because of a crack in the plug, dissolution of salt around the seal, or by some other means. Contaminated fluid then moves up the wellbore toward the ground as the pressure in the cavern is reduced to the hydrostatic value. The wellbore would have cement plugs installed during cavern closure and abandonment. With time, the well casing might deteriorate because of the presence of brine in the vicinity of the caprock or the top of the cavern if a caprock was not present. For anticipated conditions, the well casing would corrode and fail near the top of the cavern first. With additional time, the well casing would fail at shallower depths.

If the cavern had an initial brine volume of $1,000,000 \mathrm{ft}^{3}$ and it was filled to threequarters capacity with NOW and NORM, about $250,000 \mathrm{ft}^{3}$ of free brine and $750,000 \mathrm{ft}^{3}$ of waste would be present. Tomasko et al. (1997) report that if the cavern failed at a pressure equal to the lithostatic value (approximately 1,500 psi for a cavern located at a depth of $1,500 \mathrm{ft}$ ), a maximum of only about $0.1 \%$ of the free liquid (about 2,000 gal) would exit the cavern because of the effects of compressibility (Streeter 1961), assuming the wellbore was free of liquid and at atmospheric pressure. If the well bore contained water, or if the released volume was greater than the volume of the wellbore up to the location of the deepest plug, less than $0.1 \%$ of the fluid would escape from the cavern. For conservative results, this study assumes that the full $0.1 \%$ volume would be released.

Flow of the released fluid would be greatly restricted in the wellbore at the locations of the cement plugs. Flow through the cement plugs would resemble flow through a porous medium having a low hydraulic conductivity (about $1 \times 10^{-8}$ to $1 \times 10^{-5} \mathrm{~cm} / \mathrm{s}$ ); we conservatively 
assumed that the hydraulic conductivity would be similar to that of cemented sandstone (Maidment 1993). If the cavern fluid moved up the borehole at a rate equal to the saturated hydraulic conductivity of the cement (Freeze and Cherry 1979), it would have a velocity of between $3 \times 10^{-5}$ and $3 \times 10^{-2} \mathrm{ft} / \mathrm{d}$. For a cavern at a depth of $1,500 \mathrm{ft}$, fluid would not reach the surface for about 140 years if the well casing remained intact and evapotranspiration did not deplete the volume of free liquid near the ground surface.

While moving up the borehole, fluid from the cavern could also move laterally into adjoining formations if the well casing had failed. Because the casing would probably be made of ordinary steel, there is a high probability that it would fail when exposed to groundwater containing brine over a time period ranging into the thousands of years. Two possible cases are considered under this scenario: (1) the casing fails at the depth of the cavern (at or near the cavern roof) and contaminated fluid is released to a deep aquifer and (2) the casing fails at a shallow depth and releases fluid to a near-surface aquifer. The released fluid is then transported horizontally to the receptor site. Because of hydrogeological differences between the aquifers considered, these scenarios are discussed separately below.

For a deep casing failure, fluid moving up the wellbore would move into the deep aquifer and be transported laterally. The presence of low-permeability beds at shallower depths would prevent vertical transport of the contaminated fluid to overlying aquifers and the ground surface. If the wellbore had a diameter of $2 \mathrm{ft}$ and the ambient groundwater velocity was $10 \mathrm{ft} / \mathrm{yr}$, contaminated water would enter the surrounding porous medium for a period of about 0.2 year.

The extent and magnitude of contamination created by this type of release would depend on the hydrological properties of the material in the vicinity of the failed casing, the volume of fluid that was released, the duration of the discharge, and the transport properties of the contaminants. In the vicinity of the cavern, hydrological properties are unlikely to favor rapid transport of the contaminants. For example, the groundwater velocity at depth is estimated on the basis of engineering judgment to be less than $10 \mathrm{ft} / \mathrm{yr}$. Because of adsorption and subsequent retardation, contaminants (particularly metals and $\mathrm{Ra}-226$ ) would be transported at even lower velocities.

Data needed to conduct a risk assessment include not only the extent of contamination created by the release, but also the concentration of the contaminant. In general, the downstream concentrations of contaminants depend on the length of time that the cavern acts as a source of contaminated fluid. For either a release at the depth of the cavern or to a shallow aquifer, the cavern is assumed, through engineering judgement, to depressurize to conditions in the wellbore within one day, a conservative assumption. Fluid released during the depressurization would then be swept into adjacent aquifers by moving groundwater $(10 \mathrm{ft} / \mathrm{yr}$ at the depth of the cavern or $100 \mathrm{ft} / \mathrm{yr}$ for a shallow release). Under these conditions, a 2-ft wellbore would act as a source of contamination for 0.2 and 0.02 years at the depth of the cavern and in a shallow aquifer, respectively. After the system depressurized, salt creep would once again occur, and the pressure in the cavern would increase, particularly if the point of failure self-heals. Because of this 
repressurization, the seal might again fail, and the process would then repeat itself as a series of short, pulsed releases. Because the time between releases would be long (repressurization is a slow process), the pulses of contamination would not interact with each other along the flow path.

After release, the contaminants would be transported in the direction of lower hydraulic head (pressure) and would undergo sorption (loss of material to particle surfaces), dispersion (reduction in concentration produced by nonuniform fluid velocities), degradation (decrease in concentration produced by chemical or biological interactions), and radioactive decay.

Calculations for radionuclide concentrations at the receptor site were performed with a onedimensional analytical solution (Tomasko 1991; 1994) that incorporates advection, dispersion, sorption, and radioactive decay of the parent radionuclides. Progeny product activity was estimated by assuming secular equilibrium.

For transport calculations, the groundwater velocity was assumed to be $10 \mathrm{ft} / \mathrm{yr}$ and dispersion was assumed to be scale dependent; dispersivity was set equal to one-tenth of the travel distance (Lallemand-Barres and Peaudecerf 1978). Contaminant concentrations in the groundwater were evaluated at the receptor site at a time of 1,000 years in the future, a typical value for risk analyses. A compilation of contaminant concentrations for these conditions is given in Table 3. The 1,000-year value was selected for consistency with risk analyses performed for the NOW material. The risk calculations are intended to estimate the risk over the 1,000 years following cavern sealing. It is unlikely that an abandoned cavern would begin leaking immediately after being sealed. Leakage, if it occurred, would most likely begin many years after the cavern was sealed. The fate and transport models, however, estimate the concentration of contaminants at a time 1,000 years after the release of contaminants, not after cavern sealing. Therefore, the risk estimates are effectively measuring the risk over a period of time longer than 1,000 years. This provides an additional measure of conservatism to the risk estimates. Because NORM is not considered to be a low-level waste (DOE Order 5820.2A DOE 1988), more stringent calculations, such as evaluating the maximum concentration within 10,000 years (NRC 1981), is not required.

For the second alternative, the cavern seal is again assumed to fail; however, the wellbore casing at depth is assumed to be intact. Contaminated fluid would then flow up the wellbore and exit the casing at a failure point adjacent to a shallow groundwater aquifer, such as the Dockum or the Ogallala. The initial concentration of the contaminants entering the system would be the same as for the scenarios discussed above, and there would be no substantial dilution. The duration of the source term would be 10 times less than that used at depth because of the higher groundwater velocity in the shallow groundwater system $(100 \mathrm{ft} / \mathrm{yr})$. For a release to shallow groundwater, the radionuclide activities would be larger than those discussed above for releases to deep aquifers because of shorter travel time and fewer half-life decays (Table 2). In spite of the higher velocity and shorter travel time for a shallow groundwater release, the radionuclide concentrations at the receptor site 1,000 years after the release would all be much 
less than the proposed or final EPA maximum contaminant levels (MCLs). The final MCL for combined

Ra-226 and Ra-228 is $5 \mathrm{pCi} / \mathrm{L}$ (40 CFR 141.15). The EPA's proposed MCLs for Ra-226 and Ra228 are $20 \mathrm{pCi} / \mathrm{L}$ and for radon is $300 \mathrm{pCi} / \mathrm{L}$ (July 18, 1991 Federal Register, 56 FR 33050).

\subsubsection{Release of Contaminated Fluid through Cracks}

During pressurization of the cavern because of the combined effects of thermal heating and salt creep, cracks might develop that would release fluid into the surrounding material, thereby reducing the pressure in the cavern. The volume of fluid released would be a function of the pressure in the cavern, the volume of the cracks, and the crack pressure. If the pressure in the cracks was atmospheric, the volume of fluid released would be the same as that discussed under the previous scenario $(2,000 \mathrm{gal})$. However, the actual volume released could be much less if the cracks were at the local hydrostatic or lithostatic pressure. For conservative results, the volume of released fluid is assumed to be $2,000 \mathrm{gal}$.

Cracks could self-heal after fluid release because of additional salt creep. With repressurization of the cavern, the cracks could once again open and produce a series of short contaminant pulses (probably on the order of hours to days in duration). These pulses would not interact with one another because of the time needed to repressurize the cavern to a value that approaches or exceeds the local lithostatic value. Because of gradients in the lithostatic pressure, cracks would open in a vertically upward direction (Diamond 1997). With time, the contaminated fluid in the cracks could reach a deep underground aquifer and be transported laterally to the location of a potential receptor (assumed to be $1,000 \mathrm{ft}$ away from the point of release).

The contaminant concentrations at the location of the receptor 1,000 years after the release into the underground aquifer would be the same as those presented above for failure of the cavern seal with a subsequent pulsed release at the depth of the cavern. The resulting contaminant concentrations would all be much less than their associated MCLs.

\subsubsection{Release of Contaminated Fluid through Leaky Interbeds or Nonhomogeneous Zones}

For this scenario, the cavern is assumed to have a leaky interbed or heterogeneity that allows communication with the outside environment. As the cavern pressure rose because of thermal effects and salt creep, fluid would be discharged into the interbed, where it would be laterally transported under existing hydraulic gradients. Fluid velocity in the interbed is assumed to be $10 \mathrm{ft} / \mathrm{yr}$. In this way, the entire fluid volume of the cavern would eventually be discharged into surrounding material.

Assuming a cavern height of $1,750 \mathrm{ft}$ (top of cavern at a depth of $1,500 \mathrm{ft}$ plus $250 \mathrm{ft}$ of free brine), Tomasko et al. (1997) calculated that it would take about 14,000 years to discharge the cavern fluid to the interbed for a steady-state volumetric creep rate of $-0.007 \% / \mathrm{yr}$ based on 
typical salt parameters and a cavern depth of $1,500 \mathrm{ft}$. For 2 million gal of free brine in the cavern, the steady-state leak rate would, therefore, be about $150 \mathrm{gal} / \mathrm{yr}$.

The leaking brine would mix with in-situ water and be transported down gradient. Because of this mixing, the contaminant concentrations would be reduced by dilution. For a cavern with a diameter of $100 \mathrm{ft}$, an interbed thickness of $20 \mathrm{ft}$, and a groundwater velocity of $10 \mathrm{ft} / \mathrm{yr}$, the dilution factor would be 1,000 (Tomasko 1991; Tomasko et al. 1997).

Table 2 lists the contaminant concentrations at the receptor site for this scenario at a time of 1,000 years after the cavern has begun to leak. All of the concentrations are very small compared with their MCLs.

\subsubsection{Partial Cavern Roof Fall}

Loss of cavern integrity through a partial roof fall coupled with failure of the cavern seal could produce impacts similar to those described in Section 8.4.1.2. Under these conditions, the cavern would discharge fluid in a series of short pulses separated by periods of low to no discharge when the pressure in the cavern was increasing because of salt creep. If a partial roof fall occurred without failure of the cavern seal, contaminated fluid would be released in a series of short pulses. A partial roof fall coupled with a release through leaky interbeds or nonhomogeneous zones of higher permeability material would be manifested as a long, slow release. Contaminant concentrations for these various scenarios are given in Table 3.

\subsubsection{Probabilities of Occurrence}

Another factor that is needed in performing a risk assessment, in addition to the concentrations of the contaminants of concern, is the probability that a given scenario would occur. Because there is no operational history for disposing of NOW in salt caverns, the probabilities of occurrence for the release scenarios described above are uncertain. Under the most optimistic conditions, no releases would ever occur, and the associated probabilities of occurrence would be zero. For the most pessimistic conditions, releases would always occur and the probabilities of occurrence would be 1.0.

To reduce the uncertainty in the range of the probabilities of occurrence, Tomasko et al. (1997) distributed a questionnaire to experts in the field of salt disposal. The panel of experts was asked to provide both a "best-estimate" and a "worst-case" estimate of the probability of occurrence for each of the release scenarios. In the context of this questionnaire and study, best estimate did not refer to the "best-case" or the best or least risky case, but rather it referred to the probability of occurrence that was most likely in the best judgment of the expert. Similarly, "worst-case" referred to the least likely probability of occurrence in the best judgment of the expert, rather than to the most risky case. 
The estimates received from the expert panel were aggregated to form consensus values for each of the probabilities of occurrence. Table 4 lists the best-estimate and worst-case aggregated probabilities of occurrence (and their ranges) for the release scenarios previously discussed (Tomasko et al. 1997). For all cases, the highest probabilities of occurrence were for a partial fall of the roof $(0.10$ and 0.29 , respectively). The lowest probabilities of occurrence were for: (a) a partial roof fall with a cavern seal failure and release to a shallow aquifer $(0.006$ and 0.051 , respectively), and (b) a cavern seal failure with subsequent release to a shallow aquifer (0.012 and 0.040 , respectively).

To provide an even more conservative estimate, we additionally calculated the true worst case condition by assuming that all caverns would have releases during the 1,000-year period of concern (i.e., probability $=100 \%$ ). This situation is shown on Figures 4, 5, and 6 as the $100 \%$ Probability of Release case.

\subsubsection{Exposure Point Concentrations}

Section 8.4.1 provides estimates of concentrations at the receptor site $(1,000 \mathrm{ft}$ laterally from the point of release), assuming NORM constituents are released from the salt cavern. Section 8.4.2 provides best- and worst-case estimates of the probabilities that each of these release scenarios would occur. The exposure point concentration used in estimating risk is the product of the expected concentration, assuming release occurs, and the estimated probability of occurrence. Table 5 summarizes the exposure point concentrations for Ra-226 for each scenario, assuming best- and worst-case probabilities of occurrence. Exposure to Rn-222 in indoor air could also occur following volatilization during showering. A worst-case bounding estimate of potential risk associated with the inhalation pathway was evaluated on the basis of the worst-case scenario (i.e., $100 \%$ Probability of Release case, roof fall and cavern seal failure and release at shallow depth). The estimated Rn-222 exposure point concentration in groundwater for this scenario is $4 \times 10^{-9} \mathrm{pCi} / \mathrm{L}$. It was estimated that the activity concentration of $\mathrm{Rn}-222$ in indoor air following volatilization from groundwater would be $0.01 \%$ of the initial concentration in the groundwater (i.e., $4 \times 10^{-13} \mathrm{pCi} / \mathrm{L}$ ) (Milvy and Cothern 1990). The exposure point concentration, which for inhalation is expressed in units of working level (WL), is equivalent to $1 \times 10^{-15} \mathrm{WL}$ (assuming an equilibrium factor of 0.267 ).

\subsubsection{Estimation of Radiological Doses and Carcinogenic Risks}

Radiation exposure pathways can be separated into external and internal components. External exposure, which occurs when the radioactive material is outside of the body, is a concern primarily only for gamma radiation because it can easily penetrate tissue and reach internal organs. Internal exposure occurs when the radioactive material is taken into the body through inhalation or ingestion. For internal exposures, alpha and beta particles constitute the dominant concern because their energy is almost completely absorbed in cells and because of their potential for causing biological harm. For this study, the only exposure pathway considered is ingestion of groundwater, hence exposures are limited to internal exposures. 
Exposure to internally deposited radioactive contaminants is expressed in terms of the 50-year committed effective dose equivalent (CEDE). This concept, developed by the International Commission on Radiological Protection (ICRP 1977), represents the weighted sum of the dose equivalent in various organs. The CEDE incorporates consideration of the radiosensitivity of different organs, the biological effectiveness of different types of radiation, and the variable retention time in the body for different radionuclides. The unit of dose equivalent is the rem (or mrem, $10^{-3} \mathrm{rem}$ ). A rem measures the ability of a specific type of radiation to damage biological tissue.

The metabolic behavior of radium in the body is similar to that of calcium. Thus, a fraction of ingested radium is deposited in bone, where it can remain over a long period. Chronic intake of radium can result in very high concentrations in the bone and cause ionization of cellular components in bone and the subsequent mutation of affected cells. For this study, CEDEs for Ra-226 were calculated by using the appropriate dose conversion factor (DCF) provided in Federal Guidance Report 11 (EPA 1988), and the following equation:

where:

$$
\mathrm{CEDE}=\mathrm{C}_{\mathrm{i}} \times \mathrm{I}_{\mathrm{ing}} \times \mathrm{EF} \times \mathrm{ED} \times \mathrm{DCF}_{\mathrm{ing}},
$$

$\mathrm{CEDE}=$ committed effective dose equivalent (mrem),

$\mathrm{Ci}=$ exposure point concentration/activity $(\mathrm{pCi} / \mathrm{L})$,

$I_{\text {ing }}=$ ingestion rate $(\mathrm{L} /$ day $)$ - assumed to be $2 \mathrm{~L} /$ day,

$E F=$ exposure frequency $(\mathrm{d} / \mathrm{yr})-$ assumed to be $350 \mathrm{~d} / \mathrm{yr}$,

$\mathrm{ED}=$ exposure duration $(\mathrm{yr})$ - assumed to be $70 \mathrm{yr}$, and

$\mathrm{DCF}_{\text {ing }}=$ ingestion dose conversion factor for Ra-226 $\left(1.3 \times 10^{-3} \mathrm{mrem} / \mathrm{pCi}\right)$.

The resulting CEDEs are shown in Table 5. The highest estimated CEDE is $1 \times 10^{-8} \mathrm{mrem}$. For comparison purposes, Americans receive an average dose of 360 mrem per year (or roughly 36 billion times as much) from natural radiation.

Doses resulting from inhalation of radon were calculated as follows:

$$
\mathrm{WLM}=\mathrm{C}_{\mathrm{wl}} \times \mathrm{I}_{\text {inh }} \times \mathrm{ET} \times \mathrm{EF} \times \mathrm{ED} / \mathrm{CF} \text {, }
$$

where:

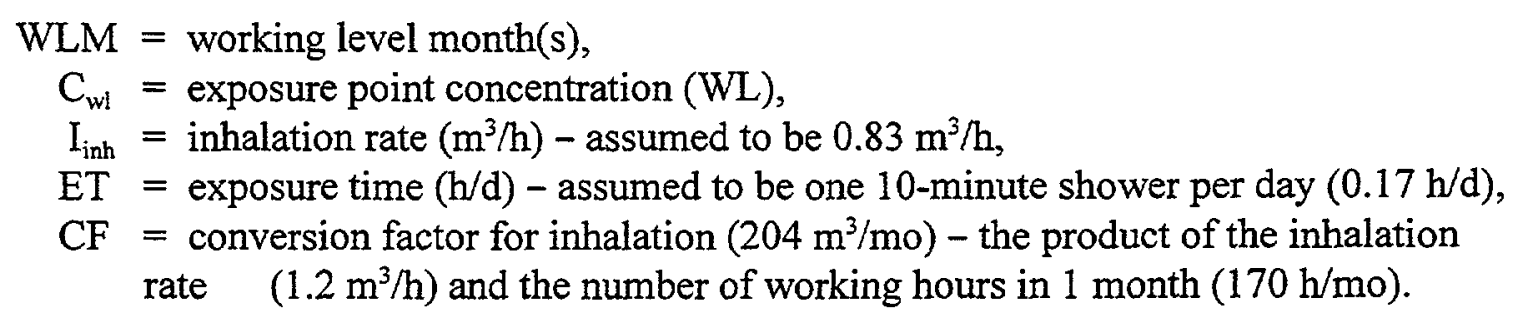


The maximum upper-bound estimate of dose to a resident from inhalation of indoor radon is $2 \times 10^{-14} \mathrm{WLM}$.

The major radiological health concern from exposure to NORM is induction of cancer. The EPA classifies all radionuclides as Group A (known) carcinogens. Radionuclides are also mutagenic (can cause genetic mutations), teratogenic (can cause birth defects), and highly toxic. However, because the cumulative risk of cancer is many times greater than the risk of genetic or teratogenic effects (EPA 1989) and because there are so few data quantifying the relationships between dose and effect for noncancer effects of low doses of Ra-226, only cancer risks are estimated in this report.

The development of radiation-induced cancer is a stochastic process and is considered to have no threshold dose (i.e., the probability of occurrence, not the severity of effect, increases with dose, and there is no dose level below which the risk is zero). The relationship between radiation dose and development of cancer is well characterized for high doses of most types of radiation, but for low doses it is not well defined. Low levels of radiation exposure may present a health risk, but it is difficult to establish a direct cause-and-effect relationship because of the lack of data and the presence of compounding environmental stresses. Therefore, the risk from low levels of radiological exposure must be extrapolated from data for increased rates of cancers observed at higher doses. For this assessment, radiation doses associated with ingestion were converted to carcinogenic risks by using risk factors given in ICRP Publication 60 (ICRP 1991). The ICRP risk factors for the public are $5 \times 10^{-7}$ per mrem for the increased probability of fatal cancer over a lifetime, and $6 \times 10^{-7}$ per mrem for the increased probability of cancer incidence over a lifetime. The estimated dose from inhalation of $\mathrm{Rn}-222$ and its decay products (in units of WLM) was converted to risk using a risk factor of $3.5 \times 10^{-4} \mathrm{per}$ WLM recommended in the BEIR IV study (National Research Council 1988).

The risk levels from Ra-226 calculated on the basis of these assumptions are shown in Table 5. The highest estimated cancer risk due to NORM released from salt caverns is $1 \times 10^{-13}$ for the $100 \%$ Probability of Release case for the failure pathway that assumes roof falls, cavern seal failures, and contaminant release at shallow depth. The lowest estimated risk, $7 \times 10^{-24}$, is for the best-estimate probability for the failure pathway in which fluid is released from a crack.

The risk from exposure to indoor $\mathrm{Rn}-222$ is insignificant (i.e., orders of magnitude lower) in comparison with the risk estimated for ingestion of groundwater. The maximum risk from inhalation of Rn-222 was estimated to be $6 \times 10^{-18}$ for the worst-case scenario (compared with the maximum risk from Ra-226 ingestion, $1 \times 10^{-13}$ ). The cancer risks presented in Table 5 for ingestion of Ra-226 in groundwater are representative of the cumulative lifetime risk resulting from all radionuclides and pathways because the incremental risk from inhalation of $\mathrm{Rn}-222$ is negligible. Estimated lifetime risks due to NORM and NOW releases from salt caverns are presented in Table 6. The maximum estimated lifetime risk from NORM is $1 \times 10^{-13}$; the maximum estimated lifetime risk from NOW is $2 \times 10^{-7}$. These maximum risks occur for the $100 \%$ Probability of Release case; the best-case and worst-case estimate scenarios have even 
lower risks. The risks from Ra-226 are several orders of magnitude lower than NOW, and they can be considered insignificant in comparison. In all cases, the estimated NORM and NOW human health risks due to ingesting groundwater contaminated with NOW and NORM releases from disposal in salt caverns are significantly below the target risk range $\left(10^{-4}\right.$ to $\left.10^{-6}\right)$ that the EPA established for remedial actions at National Priority List sites (40 CFR $300.430(\mathrm{e})(2)(\mathrm{i})(\mathrm{A})(2))$.

The chemical constituents of NORM pose a noncancer as well as a cancer risk. On the other hand, the radiological constituents of NORM are considered to pose only a cancer risk. Therefore, the noncancer risk of NORM waste is the same as the noncancer risk attributed to NOW. Tomasko et al. (1997) estimated worst-case noncancer risks (expressed as hazard quotients) for NOW ranging from $6 \times 10^{-5}$ to $1 \times 10^{-7}$. The accepted risk threshold for noncancer risks is a hazard quotient of less than 1.0.

\subsection{Uncertainties}

The approach outlined in the previous sections is subject to several uncertainties that could affect the results. However, because the estimated risks are so low, it is doubtful that resolving the uncertainties would cause the risks to increase so much that they would become significant. Uncertainties that could affect the results include the following:

- Extrapolation from high levels to low levels of radiation exposure. The estimated risks presented in this study are based on the assumption that no lower threshold exists for radiation carcinogenesis, so health effects increase linearly with radiation dose. Such extrapolation of data from studies of human populations exposed to high levels of radiation to much lower doses is a major source of uncertainty in determining the risk of cancer from exposure to low levels of ionizing radiation.

- $\quad$ Modeled exposure data. Because no waste disposal caverns have been used for NORM wastes, and no cavern used for NOW has been closed, no actual data exist for use in the analysis. Although the authors believe the models and assumptions used in this study are appropriate, there are no data to verify their accuracy.

- Effect of Background. It is difficult to distinguish background concentrations of radionuclides from introduced concentrations.

\subsection{Sensitivity of Risks to Operating Procedures and Regulatory Structures}

The risk estimates calculated above indicate that the potential for human health risks associated with disposal of NORM waste in salt caverns is very low. These risks were estimated assuming normal operating conditions and standard operating procedures for cavern closure. Any relaxation in design, monitoring, or operating practices could increase these risks. 
Although the risks associated with spills, accidents, and equipment leaks during normal operations were not evaluated in this study, it is likely that contaminants released during such occurrences would present greater risks than those derived from the cavern itself. Consequently, care should be taken to ensure that operating practices continue to be monitored in a way that minimizes the occurrence of surface accidents. 



\section{Findings and Conclusions}

NORM contamination is found in some oil field produced water, pipe scale, and sludge. Spills or releases of these materials have contaminated soil at some sites. The majority of NORM waste is currently being disposed of through underground injection, particularly at one commercial disposal facility in Texas. NORM waste is also disposed of through burial in landfills, encapsulation inside the casing of wells being plugged and abandoned, and land spreading. Several companies are now or soon will be disposing of NORM on an operator's site by treatment and disposal through the operator's injection well. This report evaluates the technical feasibility, legality, economics, and human health risk of an alternative NORM waste disposal option - disposal in salt caverns. The major findings and conclusions of the report follow.

\subsection{Technical Feasibility}

NORM waste is physically and chemically similar to nonhazardous oil field waste (NOW). Its primary difference from NOW is the presence of radionuclides in NORM waste. The presence of radionuclides may require additional safety precautions when handling the NORM waste, but the actual disposal process would be no different from that for NOW. NOW waste is currently being disposed of without difficulties in four U.S. salt caverns and in several Canadian caverns. There is no technical reason why these caverns or other future disposal caverns could not equally well accept NORM waste other than produced water, which is disposed of primarily by injection.

\subsection{Legality}

No existing federal regulations specifically address handling and disposal of NORM wastes. In the absence of federal regulations, individual states have taken responsibility for developing their own regulatory programs. These programs have been evolving rapidly over the last few years. Salt caverns used for disposal of oil field wastes are considered to be Class II injection wells under most state regulations. A review of federal UIC regulations and NORM and UIC regulations from the five states that have expressed some interest in cavern disposal indicated that there are no outright prohibitions against NORM disposal in salt caverns, except for Louisiana, which prohibits disposal of radioactive wastes or other radioactive materials in salt domes. Presently, however, only Texas and New Mexico are working on disposal cavern regulations, and no states have issued permits to allow cavern disposal of NORM waste.

\subsection{Economics}

Current NORM waste disposal costs range from $\$ 15 / \mathrm{bbl}$ to $\$ 420 / \mathrm{bbl}$. These costs reflect the information provided by disposal companies to the authors in early 1998 and may not reflect actual total disposal costs. It is also difficult to compare cost figures from one disposal company 
to another because the companies do not always include the same types of services in their quoted prices.

None of the existing Texas NOW disposal cavern operators have made even preliminary estimates of what they would charge to dispose of NORM waste if the regulatory agency gave them approval to do so. NOW disposal caverns have proven cost competitive with other NOW disposal facilities in the same geographic area. This study does not constitute a formal market analysis, and the costs to upgrade a cavern disposal operation for NOW to one that disposes of NORM waste have not been quantified. Nevertheless, there is a reasonable chance that NORM waste disposal cavern companies would be able to install the additional waste handling equipment and implement expanded monitoring and worker safety procedures and still compete economically with existing off-site commercial NORM disposal facilities once regulatory agencies allow the practice to occur.

\subsection{Human Health Risk}

Caverns are located deep below the earth's surface. The process of filling caverns with waste is performed at low pressure and should not cause cavern failure. Following cavern plugging and closure, internal cavern pressure could increase from salt creep and geothermal heating to a point at which leaks or releases might occur. Even if such releases did occur, the likelihood that contaminants would migrate off-site to a potential human health receptor site (a drinking water well) is small. On the basis of assumptions that were developed for a generic cavern and generic NORM wastes, the estimated worst-case human health risks from the chemical contaminants of NORM waste are very low (excess cancer risks of between $1 \times 10^{-8}$ and

$2 \times 10^{-17}$ ), and the hazard quotients (referring to noncancer health effects) for NOW are between $6 \times 10^{-5}$ and $1 \times 10^{-7}$. These values are identical to the risks estimated by Tomasko et al. (1997). Even under the extremely conservative $100 \%$ Probability of Release case, the highest risk from the chemical contaminants of NORM waste is $2 \times 10^{-7}$. Normally, risk managers consider risks of less than $1 \times 10^{-6}$ and hazard quotients of less than 1.0 to be acceptable. The excess cancer risks estimated for the radiological contaminants are orders of magnitude lower; even for the $100 \%$ Probability of Release Case, risks are estimated at $1 \times 10^{-13}$ to $3 \times 10^{-22}$ and, consequently, are dwarfed by the risks from the chemical contaminants. No noncancer health risks were estimated for radionuclides.

The risk calculations are intended to estimate the risk over the 1,000 years following cavern sealing. It is unlikely that an abandoned cavern would begin leaking immediately. Leakage, if it occurred, would most likely begin many years after the cavern was sealed. The fate and transport models, however, estimate the concentration of contaminants at a time 1,000 years after their release, not after cavern sealing. Therefore, the risk estimates are effectively measuring the risk over a period of time longer than 1,000 years. This provides an additional measure of conservatism to the risk estimates. 
The size of the hypothetical cavern used in these risk calculations is somewhat smaller than the existing disposal caverns in Texas. The volume of fluid released from the cavern would be proportional to the total volume of the cavern; therefore, larger caverns would release proportionately more fluid. Because actual cavern volumes are on the same order of magnitude as the hypothetical cavern, the estimated risks from the actual caverns are expected to be on the same order of magnitude as those calculated here, which remain lower than accepted risk thresholds.

\subsection{Conclusions}

This report provides evidence that cavern disposal of NORM waste poses a very low human health risk and is most likely technically feasible. From a legal perspective, there are no "fatal flaws" that would prevent a state regulatory agency from approving cavern disposal of NORM, except for Louisiana, which prohibits disposal of radioactive wastes or other radioactive materials in salt domes. Agencies in the other states may need to revise their NORM waste management or UIC regulations to accommodate the practice, however, and Louisiana would additionally need to modify its statute.

Cavern operators would probably charge more for NORM waste disposal than the $\$ 1.95 / \mathrm{bbl}$ to $\$ 6 / \mathrm{bbl}$ that they currently charge for NOW disposal. Given that those companies handling most of the NORM waste are currently charging $\$ 100 / \mathrm{bbl}$ or more for NORM waste disposal, there is probably plenty of leeway to make facility upgrades and still produce a profit. The ability for a NORM waste disposal cavern to be cost competitive looks promising, assuming regulatory agencies approve the practice. 



\section{References}

Anderson, R., 1998, personal communication between Anderson, New Mexico Energy, Minerals, and Natural Resources Department, Oil Conservation Division, Santa Fe, NM, and K.P. Smith, Argonne National Laboratory, Lakewood, CO, January 29.

API, 1994, "Design of Solution-Mined Underground Storage Practices," API Recommended Practice 1114, American Petroleum Institute, Washington, DC, June.

API, 1996, "A Naturally Occurring Radioactive Material (NORM) Disposal Cost Study," API Publication $7100,1^{\text {st }}$ edition, American Petroleum Institute, Washington, DC, November.

Back, W., J.S. Rosenshein, and P.R. Seaber, 1988, The Geology of North America, Volume O-2, The Geological Society of America, Inc., Boulder, CO.

Bair, E.S., 1987, "Analysis of Hydraulic Gradients Across the Host Rock at the Proposed Texas Panhandle Nuclear-Waste Repository Site," Ground Water 25(4):440-447.

Bair, E.S., T.P.O. O'Donnell, and L.W. Picking, 1985, "Potentiometric Mapping from Incomplete Drill-Stem Test Data: Palo Duro Basin Area, Texas and New Mexico," Ground Water 23(2):

198-211.

Bassett, R.L., and M.E. Bentley, 1982, "Geochemistry and Hydrodynamics of Deep Formation Brines in the Palo Duro and Dalhart Basins, Texas, U.S.A.," Journal of Hydrology 59:331-372.

Berest, P., and B. Brouard, 1995, "Behavior of Sealed Solution-Mined Caverns," presented at the Spring Meeting of the Solution Mining Research Institute, New Orleans, LA, April.

Berest, P., B. Brouard, J. Bergues, J. Frelat, and G. Durup, 1997, "Salt Caverns and the Compressibility Factor," presented at the Fall Meeting of the Solution Mining Research Institute, El Paso, TX, October.

Bishop, W.M., 1986, "Long-Term Disposition of SPR Caverns Not Used for Petroleum Storage, A Draft Plan," unpublished report, employed by PB-KBB, Houston, TX, October.

Blanco, R.J., 1996, letter from Blanco, Acting Director of EPA's Ground Water Protection Division, Washington, DC, to M.J. Paque, Executive Director of the Ground Water Protection Council, Oklahoma City, OK, on the types of waste that can be disposed of in Class II wells, June 26.

Brown, B., and O. Helmer, 1964, "Improving the Reliability of Estimates Obtained from a Consensus of Experts," P-2986, The RAND Corporation, Santa Monica, CA. 
Bush, T.O., 1998, fax from Bush, BPF, Inc., Duncanville, TX, to K. Smith, Argonne National Laboratory, Denver, CO, January 15.

Capone, D.W., S. Chatterjee, T. Cleland, D. Fortunato, G. Roehrig, H.B. Walker, and T.O. Bush, 1997, "Results of Bench Scale Testing of a Mobile On-Site NORM Treatment System in Texas and New Mexico," in proceedings of U.S. Department of Energy's Natural Gas Conference, Houston, TX, March 24-27.

Capuano, R.M., and R.Z. Jan, 1996, "In-Situ Hydraulic Conductivity of Clay and Silt-Clay Fluvial-Deltaic Sediments, Texas Gulf Coast," Ground Water 34(3):545-551.

Chilingarian, G.V., J.O. Robertson, Jr., and S. Kumar, 1989, Surface Operations in Petroleum Production, II, Elsevier, New York.

CSA, 1993, "Storage of Hydrocarbons in Underground Formations - Oil and Gas Industry Systems and Materials," Standard Z341-93, Canadian Standards Association, Rexdale, Ontario, Canada, July.

Diamond, H.W., 1997, letter from Diamond, Solution Mining Research Institute, Deerfield, IL, to J. Veil, Argonne National Laboratory, Washington, DC, August 6.

DOE, 1988, "Radioactive Waste Management," Order DOE 5820.2A, U.S. Department of Energy, September 26.

DOE, 1990, "Final Supplemental Environmental Impact Statement, Waste Isolation Pilot Plant," DOE/EIS-0026-FS, U.S. Department of Energy, Office of Environmental Restoration and Waste Management, January.

EPA, 1987, "Report to Congress, Management of Wastes from the Exploration, Development, and Production of Crude Oil, Natural Gas, and Geothermal Energy," Volume 1 of 3, EPA/530SW-88-003, U.S. Environmental Protection Agency, Office of Solid Waste and Emergency Response, Washington, DC, December.

EPA, 1988, "Limiting Values of Radionuclide Intake and Air Concentration and Dose Conversion Factors for Inhalation, Submersion, and Ingestion," Federal Guidance Report No. 11, EPA-520/1-88-020, U.S. Environmental Protection Agency, September.

EPA, 1989, "Risk Assessment Guidance for Superfund, Volume I, Human Health Evaluation Manual (Part A)," EPA/540/1-89/002, U.S. Environmental Protection Agency, Office of Emergency and Remedial Response, December.

EPA, 1993, "Draft Diffuse NORM-Waste Characterization and Preliminary Risk Assessment," U.S. Environmental Protection Agency, Office of Radiation and Indoor Air, Washington, DC. 
EPA, 1994, "Associated Waste Report: Crude Oil Tank Bottoms and Oily Debris," U.S. Environmental Protection Agency, Office of Solid Waste, Special Waste Branch, Washington, DC, March.

Fiddler, L., 1998, personal communication between Fiddler, Oklahoma Corporation Commission, UIC Department, Oklahoma City, OK, and K.P. Smith, Argonne National Laboratory, Lakewood, CO, July 13.

Ford, W.K., 1998, personal communication between Ford, Mississippi State Oil and Gas Board, Jackson, MS, and K.P. Smith, Argonne National Laboratory, Lakewood, CO, January 28.

Freeze, R.A., and J.A Cherry, 1979, Groundwater, Prentice-Hall, Inc., Englewood Cliffs, NJ.

Freeze, G.A., K.W. Larson, P.B. Davies, and S.W. Webb, 1995, "Using a Multiphase Flow Code to Model the Coupled Effects of Repository Consolidation and Multiphase Brine and Gas Flow at the Waste Isolation Pilot Plant," AIChE Heat Transfer Symposium, Portland, Oregon, E.L. Gaden, Jr., Series Editor, Volume 91, Number 306, American Institute of Chemical Engineers, NY.

Ginn, R., 1998, personal communication between Ginn, Texas Railroad Commission, Environmental Services, Austin, TX, and K.P. Smith, Argonne National Laboratory, Lakewood, Co, January 29 and July 7.

Graves, B., 1989, Radon in Ground Water, Proceedings of the NWWA Conference, Somerset, NJ, April.

Hanor, J.S., 1993, "Effective Hydraulic Conductivity of Fractured Clay Beds at a Hazardous Waste Landfill, Louisiana Gulf Coast," Water Resources Research 29 (11): 3691-3698.

Hickerson, R., 1995, "Oilfield Waste Disposal in a Salt Cavern," in Proceedings of the Annual Underground Injection Control and Ground Water Protection Forum, Kansas City, MO, October.

ICRP, 1977, "Recommendations of the Commission on Radiological Protection," ICRP Publication 26, Annals of the ICRP 1(3), Commission on Radiological Protection, Pergamon Press, New York, adopted January 17.

ICRP, 1991, "1990 Recommendations of the International Commission on Radiological Protection," ICRP Publication 60, International Commission on Radiological Protection, Pergamon Press, Oxford, United Kingdom.

IOGCC, 1995, "Natural Gas Storage in Salt Caverns - A Guide for State Regulators," Interstate Oil and Gas Compact Commission, Oklahoma City, OK, October. 
Kelly, J., 1998, letter from Kelly, Lotus LLC, Andrews, TX, to J.Veil, Argonne National Laboratory, Washington, DC, January 9, and personal communication between Kelly and Veil, June 3.

Lallemand-Barres, A., and P. Peaudecerf, 1978, "Recherche des Relations Entre la Valeur de la Dispersivite Macroscopique d'un Milieu Aquifere, Ses Autres Caracteristiques et les Conditions de Mesure," Bulletin Bureau Geologique Minieres, Sect. 3, Vol. 4, pp. 277-284.

Langer, M., M. Wallner, and H. Wassman, 1984, "Gebirgsmechanische Bearbeitung von Stabilatsfragen bei Deponiekaverenen im Salzgebirge" (Geoengineering with Respect to Stability of Cavities Used for Disposal Purposes, in German), Kali und Steinsalz, 2, pp. 66-76.

Linn, J., 1997, personal communication between Linn, Sandia National Laboratories, Albuquerque, NM, and D. Tomasko, Argonne National Laboratory, Argonne, IL, February.

Maidment, D.R., 1993, Handbook of Hydrology, McGraw-Hill, Inc., New York.

McArthur, A., M. Major, and D.J. Lowe, 1995, "NORM Disposal in Class II Wells," SPE paper 29713, presented at the Society of Petroleum Engineers/Environmental Protection Agency Exploration \& Production Environmental Conference, Houston, TX, March 27-29.

MDEQ, 1996, "Cleanup and Disposal Guidelines for Sites Contaminated with Radium-226," Drinking Water and Radiological Protection Division, Michigan Department of Environmental Quality, Lansing, MI.

Milvy, P., and C.R. Cothern, 1990, "Scientific Background for the Development of Regulations for Radionuclides in Drinking Water," in Radon, Radium, and Uranium in Drinking Water, C.R. Cothern and P.A. Rebers (editors), Lewis Publishers, Chelsea, MI.

Moore, G., 1998, personal communication between Moore, Taylor Invesco LLC, Carthage, TX, and J.Veil, Argonne National Laboratory, Washington, DC, January 28.

National Research Council, 1988, Health Risks of Radon and Other Internally Deposited AlphaEmitters, BEIR IV Report, report of the Committee on the Biological Effects of Ionizing Radiations, National Academy Press, Washington, D.C.

NRC, 1981, "Draft Environmental Impact Statement on 10 CFR Part 61 'Licensing Requirements for Land Disposal of Radioactive Waste'," NUREG-0782, Vol. 2, U.S. Nuclear Regulatory Commission, Office of Nuclear Material Safety and Safeguards, Washington, DC, September.

Page, W., and N. Guidry, 1998, personal communication between Page and Guidry, National Injection Services, Inc., Lafayette, LA, and J.Veil, Argonne National Laboratory, Washington, DC, February 11. 
Pfeifle, T.W., T.J. Vogt, and G.A. Brekken, 1995, "Correlation of Chemical, Mineralogic, and Physical Characteristics of Gulf Coast Dome Salt to Deformation and Strength Properties," Research Project Report 94-0004-S, Solution Mining Research Institute, Deerfield, IL, January.

Querio, C.W., 1980, "Design and Construction of Solution-Mined Caverns for LPG Storage," presented at the Fall Meeting of the Solution Mining Research Institute, Minneapolis, MN, October.

Radian Corporation, 1995, "Risk Assessment of Converting Salt Caverns to Natural Gas Storage, Final Report," GRI-95/0377, prepared for the Gas Research Institute, Austin, TX, October.

Rafati, A., 1998, personal communication between Rafati, Envirocare of Utah, Inc., Salt Lake City, UT, and J.Veil, Argonne National Laboratory, Washington, DC, February 11.

Reddoch, J., 1998, personal communication between Reddoch, Apollo Services, Lafayette, LA, and J.Veil, Argonne National Laboratory, Washington, DC, January 21.

Richey, S.F., J.G. Wells, and K.T. Stephens, 1985, "Geohydrology of the Delaware Basin and Vicinity, Texas and New Mexico," Water Resources Investigations Report 84-4077, U.S. Geological Survey, Albuquerque, NM.

Sammons, J., 1998, personal communication between Sammons, Newpark Environmental Services, Houston, TX, and J.Veil, Argonne National Laboratory, Washington, DC, January 23.

Sanford, W.E., R.G. Shropshire, and D.K. Solomon, 1996, "Dissolved Gas Tracers in Groundwater: Simplified Injection, Sampling, and Analysis," Water Resources Research 32(6):1635-1642.

Scaife, W.W., S.G. Mueller, and D.R. Young, 1994, "Downhole Disposal of NORM Wastes in An Offshore Setting: Lessons Learned," in Proceedings of the International Petroleum Environmental Conference, Houston, TX, March 2-4.

Seni, S.J., 1980, "Sand-Body Geometry and Depositional Systems, Ogallala Formation, Texas," Bureau of Economic Geology Report of Investigation No. 5, University of Texas, Austin, TX.

Sheppard, M.I., D.I. Beals, D.H. Thibault, and P. O'Connor, 1984, "Soil Nuclide Distribution Coefficients and Their Statistical Distributions," AECL-8364, Whiteshell Nuclear Research Establishment, Atomic Energy of Canada Limited, Pinawa, Manitoba, December.

Sipple-Srinivasan, M., M.S. Bruno, R.A. Bilak, and P.G. Danyluk, 1997, "Field Experiences with Oilfield Waste Disposal through Slurry Fracture Injection," SPE paper 38254, presented at 
$67^{\text {th }}$ Annual Western Regional Meeting of the Society of Petroleum Engineers, Long Beach, CA, June 23-27.

Smith, K.P., D.L. Blunt, G.P. Williams, and C.L. Tebes, 1996, "Radiological Dose Assessment Related to Management of Naturally Occurring Radioactive Materials Generated by the Petroleum Industry," ANL/EAD-2, Argonne National Laboratory, Argonne, IL, September.

Streeter, V.L., 1961, Handbook of Fluid Dynamics, McGraw-Hill Book Company, Inc., New York.

Talbot, , J., 1998, personal communication between Talbot, Louisiana Department of Natural Resources, Office of Conservation, Baton Rouge, LA, and K.P. Smith Argonne National Laboratory, Lakewood, CO, July 9.

Tanner, A.B., 1964, "Radon Migration in the Ground: A Review," The Natural Radiation Environment, Rice University, University of Chicago Press, Chicago, IL.

Testa, S.A., 1994, Geological Aspects of Hazardous Waste Management, CRC Press, Boca Raton, FL.

Tomasko, D., 1985, "A Numerical Model for Predicting the Thermal Behavior of Caverns in the Strategic Petroleum Reserve," Dissertation submitted in partial fulfillment of the requirements for the degree of Doctor of Philosophy, the University of New Mexico, Albuquerque, NM.

Tomasko, D., 1991, "Modeling Vertical and Horizontal Solute Transport," American Geophysical Union Fall Meeting, San Francisco, CA, December.

Tomasko, D., 1994, "An Analytical Model for LNAPL Transport in the Vadose Zone," Geological Society of America Fall Meeting, Seattle, WA, December.

Tomasko, D., D. Elcock, J. Veil, and D. Caudle, 1997, "Risk Analyses for Disposing Nonhazardous Oil Field Wastes in Salt Caverns," prepared for U.S. Department of Energy, Office of Fossil Energy, Argonne National Laboratory, Argonne, IL, December.

Veil, J.A., 1997, "Costs for Off-Site Disposal of Nonhazardous Oil Field Wastes: Salt Caverns versus Other Disposal Methods," DOE/BC/W-31-109-Eng-38-2, prepared for U.S. Department of Energy, National Petroleum Technology Office, September.

Veil, J., D. Elcock, M. Raivel, D. Caudle, R.C. Ayers, Jr., and B. Grunewald, 1996, "Preliminary Technical and Legal Evaluation of Disposing of Nonhazardous Oil Field Waste into Salt Caverns," prepared for the U.S. Department of Energy, Office of Fossil Energy, by Argonne National Laboratory, Washington, DC, June. 
Wallner, M., 1986, "Frac-Pressure Risk in Rock Salt," presented at the Fall Meeting of the Solution Mining Research Institute, Amsterdam.

Wallner, M., and W.A. Paar, 1997, "Risk of Progressive Pressure Build Up in a Sealed Cavern," presented at the Fall Meeting of the Solution Mining Research Institute, El Paso, TX, October.

Werner, M.L, 1986, "Structure and Mineralization of the Richton Dome Caprock Boring MRIG9, Technical Report," BMI/ONWI-610, Office of Nuclear Waste Isolation, Columbus, OH.

White, C., 1998, letter from White, US Ecology, Richland, WA, to J.Veil, Argonne National Laboratory, Washington, DC (received in January).

Whiting, G.H., 1981, "Strategic Petroleum Reserve (SPR) Geologic Site Characterization Report, Sulphur Mines Salt Dome," SAND80-7141, Sandia National Laboratories, Albuquerque, NM, March.

Williams, T.A., and A.K. Williamson, 1989, "Estimating Water-Table Altitudes for Regional Ground-Water Flow Modeling, U.S. Gulf Coast," Ground Water 27(3):333-340.

Wood, W.W., and W.E. Sanford, 1995, "Chemical and Isotopic Methods for Quantifying Ground-Water Recharge in a Regional, Semiarid Environment," Ground Water 33(3):458-468. 

Table 1 - 1992 NORM Disposal Costs (from API 1996)

\begin{tabular}{|c|c|c|c|c|}
\hline \multirow[b]{2}{*}{$\begin{array}{l}\text { Disposal } \\
\text { Method }\end{array}$} & \multicolumn{3}{|c|}{ Disposal Cost per 55-gal Drum } & \multirow[b]{2}{*}{ Additional Costs } \\
\hline & Low & Average & High & \\
\hline $\begin{array}{l}\text { Landfill - } \\
\text { Washington }\end{array}$ & $\$ 395$ & $\$ 515$ & $\$ 730$ & None \\
\hline Landfill - Utah & $\$ 300$ & $\$ 500$ & $\$ 700$ & $\begin{array}{l}\text { Radiological analysis, physical } \\
\text { properties check, transportation, } \\
\text { waste profile, decontamination of } \\
\text { vehicle }\end{array}$ \\
\hline $\begin{array}{l}\text { Surface } \\
\text { treatment - } \\
\text { Louisiana }\end{array}$ & $\$ 100$ & $\$ 210$ & $\$ 325$ & $\begin{array}{l}\text { Radiological and chemical analysis, } \\
\text { physical properties check, } \\
\text { transportation, waste profile, packing }\end{array}$ \\
\hline Injection - Texas & $\$ 49$ & $\$ 206$ & $\$ 1,000$ & $\begin{array}{l}\text { Radiological and chemical analysis, } \\
\text { physical properties check, } \\
\text { transportation, waste profile, packing }\end{array}$ \\
\hline $\begin{array}{l}\text { Recycling steel - } \\
\text { China }\end{array}$ & \multicolumn{4}{|c|}{ No cost - steel purchase price pays for transportation costs } \\
\hline $\begin{array}{l}\text { Encapsulation in } \\
\text { pipes and } \\
\text { disposal in } \\
\text { abandoned wells }\end{array}$ & $\$ 792$ & $\$ 1,081$ & $\$ 3,333$ & None \\
\hline $\begin{array}{l}\text { Injection into } \\
\text { private wells }\end{array}$ & $\$ 151$ & $\$ 916$ & $\$ 2,300$ & None \\
\hline
\end{tabular}


Table 2 - 1998 Commercial Disposal Costs for NORM

\begin{tabular}{|l|l|l|l|}
\hline Disposal Company & Disposal Method & On-site/Off-site & Costs $(\$ / \mathrm{bbl})$ \\
\hline $\begin{array}{l}\text { Newpark Environmental } \\
\text { Services, Inc. }\end{array}$ & Injection & Off-site & $\$ 150$ \\
\hline Lotus LLC & Injection & Off-site & $\$ 100$ \\
\hline US Ecology & Landfill & Off-site & $\$ 380-\$ 420$ \\
\hline Envirocare of Utah, Inc. & Landfill & Off-site & $\begin{array}{l}\text { Variable - no costs } \\
\text { provided }\end{array}$ \\
\hline BPF, Inc. & Treatment/injection & On-site & $\$ 140^{\mathrm{a}}$ \\
\hline Apollo Services & Injection & On-site & $\$ 100-\$ 300$ \\
\hline National Injection Services & Injection & On-site & $\$ 15-\$ 150$ \\
\hline
\end{tabular}

${ }^{a} \mathrm{BPF}$ is not in commercial operation as of summer 1998. The costs presented here are projected costs for commercial-scale operation. 
Table 3 - Summary Table of NORM Activities for Release Scenarios

\begin{tabular}{|c|c|c|c|c|}
\hline Release & Contaminant & Retardation & $\begin{array}{l}\text { Initial } \\
\text { Activity } \\
\text { Concentration } \\
(\mathrm{pCi} / \mathrm{L})\end{array}$ & $\begin{array}{l}\text { Activity } \\
\text { Concentration at } \\
1,000 \mathrm{yr}(\mathrm{pCi} / \mathrm{L}) \\
\text { after Contaminant } \\
\text { Migrates Away } \\
\text { from Cavern }\end{array}$ \\
\hline \multirow{2}{*}{$\begin{array}{l}\text { Cavern seal fails, } \\
\text { releases fluid at depth }\end{array}$} & $\mathrm{Ra}-226$ & 850 & 1,500 & $8.1 \times 10^{-18}$ \\
\hline & $R n-222$ & 1 & 1,500 & $8.1 \times 10^{-18}$ \\
\hline \multirow{2}{*}{$\begin{array}{l}\text { Cavern seal fails, } \\
\text { releases fluid to shallow } \\
\text { aquifer }\end{array}$} & Ra-226 & 850 & 1,500 & $4.1 \times 10^{-9}$ \\
\hline & Rn-222 & 1 & 1,500 & $4.1 \times 10^{-9}$ \\
\hline \multirow[t]{2}{*}{ Release from crack } & Ra-226 & 850 & 1,500 & $8.1 \times 10^{-18}$ \\
\hline & $\mathrm{Rn}-222$ & 1 & 1,500 & $8.1 \times 10^{-18}$ \\
\hline \multirow{2}{*}{$\begin{array}{l}\text { Release from leaky } \\
\text { interbed }\end{array}$} & Ra-226 & 850 & 1,500 & $1.5 \times 10^{-13}$ \\
\hline & $\mathrm{Rn}-222$ & 1 & 1,500 & $1.5 \times 10^{-13}$ \\
\hline \multirow{2}{*}{$\begin{array}{l}\text { Roof fall }+ \text { release at } \\
\text { depth through crack }\end{array}$} & $\mathrm{Ra}-226$ & 850 & 1,500 & $8.1 \times 10^{-18}$ \\
\hline & $\mathrm{Rn}-222$ & 1 & 1,500 & $8.1 \times 10^{-18}$ \\
\hline \multirow{2}{*}{$\begin{array}{l}\text { Roof fall + release at } \\
\text { depth through leaky } \\
\text { interbed }\end{array}$} & $\mathrm{Ra}-226$ & 850 & 1,500 & $1.5 \times 10^{-13}$ \\
\hline & $\mathrm{Rn}-222$ & 1 & 1,500 & $1.5 \times 10^{-13}$ \\
\hline \multirow{2}{*}{$\begin{array}{l}\text { Roof fall }+ \text { cavern seal } \\
\text { failure }+ \text { release at depth }\end{array}$} & Ra-226 & 850 & 1,500 & $8.1 \times 10^{-18}$ \\
\hline & $\mathrm{Rn}-222$ & 1 & 1,500 & $8.1 \times 10^{-18}$ \\
\hline \multirow{2}{*}{$\begin{array}{l}\text { Roof fall + cavern seal } \\
\text { failure }+ \text { release at } \\
\text { shallow depth }\end{array}$} & Ra-226 & 850 & 1,500 & $4.1 \times 10^{-9}$ \\
\hline & $\mathrm{Rn}-222$ & 1 & 1,500 & $4.1 \times 10^{-9}$ \\
\hline
\end{tabular}


Table 4 - Probabilities of Occurrence for Specified Release Scenarios

\begin{tabular}{|l|l|l|l|l|l|l|}
\hline Release Scenario & $\begin{array}{l}\text { No. of } \\
\text { Response } \\
\mathrm{s}\end{array}$ & $\begin{array}{l}\text { Best-Case } \\
\text { Estimate }\end{array}$ & Range & $\begin{array}{l}\text { Worst-Case } \\
\text { Estimate }\end{array}$ & Range & $\begin{array}{l}100 \% \\
\text { Probability } \\
\text { of Release }^{\mathrm{C}} \text { Case }^{\mathrm{c}}\end{array}$ \\
\hline $\begin{array}{l}\text { Cavern seal fails, } \\
\text { releases fluid at } \\
\text { depth }\end{array}$ & 5 & 0.031 & $\begin{array}{l}0.0005 \text { to } \\
0.1\end{array}$ & 0.12 & $\begin{array}{l}0.002 \text { to } \\
0.25\end{array}$ & 1.0 \\
\hline $\begin{array}{l}\text { Cavern seal fails, } \\
\text { releases fluid to } \\
\text { shallow aquifer }\end{array}$ & 5 & 0.012 & $\begin{array}{l}0.0001 \text { to } \\
0.05\end{array}$ & 0.040 & $\begin{array}{l}0.001 \text { to } \\
0.10\end{array}$ & 1.0 \\
\hline $\begin{array}{l}\text { Release from } \\
\text { crack }\end{array}$ & 5 & 0.022 & $\begin{array}{l}0.0001 \text { to } \\
0.10\end{array}$ & 0.120 & $\begin{array}{l}0.001 \text { to } \\
0.35\end{array}$ & 1.0 \\
\hline $\begin{array}{l}\text { Leaky interbeds } \\
\text { release fluid at } \\
\text { depth }\end{array}$ & 5 & 0.022 & $\begin{array}{l}0.0001 \text { to } \\
0.10\end{array}$ & 0.120 & $\begin{array}{l}0.001 \text { to } \\
0.35\end{array}$ & 1.0 \\
\hline $\begin{array}{l}\text { Roof fall + release } \\
\text { at depth through } \\
\text { crack }\end{array}$ & 5 & 0.100 & $10^{-6}$ to 0.50 & 0.290 & $10^{-5}$ to 1.0 & 1.0 \\
\hline $\begin{array}{l}\text { Roof fall + release } \\
\text { at depth through } \\
\text { leaky interbed }\end{array}$ & 5 & 0.062 & $\begin{array}{l}5 \times 10^{-6} \text { to } \\
0.2\end{array}$ & 0.163 & $\begin{array}{l}2 \times 10^{-5} \text { to } \\
0.35\end{array}$ & 1.0 \\
\hline $\begin{array}{l}\text { Roof fall + cavern } \\
\text { seal failure }+ \\
\text { release at depth }\end{array}$ & 5 & 0.062 & $\begin{array}{l}5 \times 10^{-6} \text { to } \\
0.2\end{array}$ & 0.163 & $\begin{array}{l}2 \times 10^{-5} \text { to } \\
0.35\end{array}$ & 1.0 \\
\hline $\begin{array}{l}\text { Roof fall + cavern } \\
\text { seal failure }+ \\
\text { release at shallow } \\
\text { depth }\end{array}$ & 5 & 0.006 & $\begin{array}{l}1 \times 10^{-7} \text { to } \\
0.02\end{array}$ & 0.051 & $\begin{array}{l}1 \times 10^{-6} \text { to } \\
0.10\end{array}$ & 1.0 \\
\hline
\end{tabular}

${ }^{a}$ Most likely probability of the release scenario occurring as estimated by an expert panel.

${ }^{b}$ Least likely probability of the release scenario occurring as estimated by an expert panel.

${ }^{c}$ Probability that the release scenario will occur at every cavern during the 1,000 -yr period of concern (the true worst-case circumstance). 
Table 5 - Exposure Point Concentrations, Committed Effective Dose Equivalents, and Carcinogenic Risks Estimated for Ingestion of Ra-226 in Groundwatera

\begin{tabular}{|c|c|c|c|c|c|c|c|c|c|}
\hline & \multicolumn{3}{|c|}{ Best-Case Probability Estimates } & \multicolumn{3}{|c|}{ Worst-Case Probability Estimates } & \multicolumn{3}{|c|}{$100 \%$ Probability of Release Case } \\
\hline Release Scenario & $\begin{array}{c}\text { Exposure-point } \\
\text { Concentration } \\
(\mathrm{pC} \mathrm{C} / \mathrm{L})\end{array}$ & \begin{tabular}{|c|} 
Committed \\
Effective Dose \\
Equivalent \\
\end{tabular} & $\begin{array}{c}\text { Estimated } \\
\text { Cancer Risk }\end{array}$ & $\begin{array}{c}\text { Exposure-point } \\
\text { Concentration } \\
(\mathrm{pCi} / \mathrm{L})\end{array}$ & \begin{tabular}{|c|} 
Committed \\
Effective Dose \\
Equivalent \\
\end{tabular} & $\begin{array}{c}\text { Estimated } \\
\text { Cancer Risk }\end{array}$ & $\begin{array}{c}\text { Exposure-point } \\
\text { Concentration } \\
(\mathrm{pCi} / \mathrm{L})\end{array}$ & \begin{tabular}{|c|} 
Committed \\
Effective Dose \\
Equivalent \\
\end{tabular} & $\begin{array}{c}\text { Estimated } \\
\text { Cancer Risk }\end{array}$ \\
\hline $\begin{array}{l}\text { Cavern seal fails, } \\
\text { releases fluid at } \\
\text { depth }\end{array}$ & $3 \times 10^{-19}$ & $2 \times 10^{-17}$ & $1 \times 10^{-23}$ & $1 \times 10^{-18}$ & $6 \times 10^{-17}$ & $4 \times 10^{-23}$ & $8 \times 10^{-18}$ & $5 \times 10^{-16}$ & $3 \times 10^{-22}$ \\
\hline $\begin{array}{l}\text { Cavern seal fails, } \\
\text { releases fluid to } \\
\text { shallow aquifer }\end{array}$ & $5 \times 10^{-11}$ & $3 \times 10^{-9}$ & $2 \times 10^{-15}$ & $2 \times 10^{-10}$ & $1 \times 10^{-8}$ & $6 \times 10^{-15}$ & $4 \times 10^{-9}$ & $2 \times 10^{-7}$ & $1 \times 10^{-13}$ \\
\hline Release from crack & $2 \times 10^{-19}$ & $1 \times 10^{-17}$ & $7 \times 10^{-24}$ & $1 \times 10^{-18}$ & $6 \times 10^{-17}$ & $4 \times 10^{-23}$ & $8 \times 10^{-18}$ & $5 \times 10^{-16}$ & $3 \times 10^{-22}$ \\
\hline $\begin{array}{l}\text { Release from leaky } \\
\text { interbed }\end{array}$ & $3 \times 10^{-15}$ & $2 \times 10^{-13}$ & $1 \times 10^{-19}$ & $2 \times 10^{.14}$ & $1 \times 10^{-12}$ & $7 \times 10^{-19}$ & $2 \times 10^{-13}$ & $1 \times 10^{-11}$ & $5 \times 10^{-18}$ \\
\hline $\begin{array}{l}\text { Roof fall + release at } \\
\text { depth through crack }\end{array}$ & $8 \times 10^{.19}$ & $5 \times 10^{-17}$ & $3 \times 10^{-23}$ & $2 \times 10^{-18}$ & $1 \times 10^{-16}$ & $9 \times 10^{-23}$ & $8 \times 10^{-18}$ & $5 \times 10^{-16}$ & $3 \times 10^{-22}$ \\
\hline $\begin{array}{l}\text { Roof fall }+ \text { release at } \\
\text { depth through leaky } \\
\text { interbed }\end{array}$ & $9 \times 10^{-15}$ & $6 \times 10^{-13}$ & $4 \times 10^{-19}$ & $2 \times 10^{-14}$ & $2 \times 10^{-12}$ & $9 \times 10^{-19}$ & $2 \times 10^{-13}$ & $1 \times 10^{-11}$ & $5 \times 10^{-18}$ \\
\hline $\begin{array}{l}\text { Roof fall + cavern } \\
\text { seal failure + release } \\
\text { at depth }\end{array}$ & $5 \times 10^{-19}$ & $3 \times 10^{-17}$ & $2 \times 10^{-23}$ & $1 \times 10^{-18}$ & $8 \times 10^{-17}$ & $5 \times 10^{-23}$ & $8 \times 10^{-18}$ & $5 \times 10^{-16}$ & $3 \times 10^{-22}$ \\
\hline $\begin{array}{l}\text { Roof fall + cavern } \\
\text { seal failure }+ \text { release } \\
\text { at shallow depth }\end{array}$ & $2 \times 10^{-11}$ & $2 \times 10^{-9}$ & $9 \times 10^{-16}$ & $2 \times 10^{-10}$ & $1 \times 10^{-8}$ & $8 \times 10^{-15}$ & $4 \times 10^{-9}$ & $2 \times 10^{-7}$ & $1 \times 10^{-13}$ \\
\hline
\end{tabular}

a Risks presented in this table are solely from the radiological constituents of NORM and do not include any risks from the chemical constituents of NORM. 
Table 6 - Estimated Cancer Risks and Hazard Quotients from NORM and NOW

\begin{tabular}{|c|c|c|c|c|c|c|c|c|c|}
\hline \multirow[b]{3}{*}{ Release Scenario } & \multicolumn{3}{|c|}{ Best-Case Estimate } & \multicolumn{3}{|c|}{ Worst-Case Estimate } & \multicolumn{3}{|c|}{$100 \%$ Probability of Release Case } \\
\hline & \multicolumn{2}{|c|}{ Cancer Risk } & \multirow{2}{*}{$\begin{array}{l}\text { Hazard } \\
\text { Quotient }\end{array}$} & \multicolumn{2}{|c|}{ Cancer Risk } & \multirow{2}{*}{$\begin{array}{l}\text { Hazard } \\
\text { Quotient }\end{array}$} & \multicolumn{2}{|c|}{ Cancer Risk } & \multirow{2}{*}{$\begin{array}{l}\text { Hazard } \\
\text { Quotient }\end{array}$} \\
\hline & NOW ${ }^{\mathrm{a}}$ & NORM $^{b}$ & & NOW $^{\mathrm{a}}$ & NORM $^{b}$ & & NOW $^{\mathrm{a}}$ & NORM $^{b}$ & \\
\hline $\begin{array}{l}\text { Cavern seal fails, releases } \\
\text { fluid at depth }\end{array}$ & $5 \times 10^{-18}$ & $1 \times 10^{-23}$ & $7 \times 10^{-8}$ & $2 \times 10^{-17}$ & $4 \times 10^{-23}$ & $3 \times 10^{-7}$ & $2 \times 10^{-16}$ & $3 \times 10^{-22}$ & $2 \times 10^{-6}$ \\
\hline $\begin{array}{l}\text { Cavern seal fails, releases } \\
\text { fluid to shallow aquifer }\end{array}$ & $3 \times 10^{-9}$ & $2 \times 10^{-15}$ & $1 \times 10^{-5}$ & $9 \times 10^{-9}$ & $6 \times 10^{-15}$ & $5 \times 10^{-5}$ & $2 \times 10^{-7}$ & $1 \times 10^{-13}$ & $1 \times 10^{-3}$ \\
\hline Release from crack & $4 \times 10^{-18}$ & $7 \times 10^{-24}$ & $5 \times 10^{-8}$ & $2 \times 10^{-17}$ & $4 \times 10^{-23}$ & $3 \times 10^{-7}$ & $2 \times 10^{-16}$ & $3 \times 10^{-22}$ & $2 \times 10^{-6}$ \\
\hline $\begin{array}{l}\text { Release from leaky } \\
\text { interbed }\end{array}$ & $3 \times 10^{-16}$ & $1 \times 10^{-19}$ & $2 \times 10^{-8}$ & $1 \times 10^{-15}$ & $7 \times 10^{-19}$ & $1 \times 10^{-7}$ & $1 \times 10^{-14}$ & $5 \times 10^{-18}$ & $6 \times 10^{-7}$ \\
\hline $\begin{array}{l}\text { Roof fall + release at depth } \\
\text { through crack }\end{array}$ & $2 \times 10^{-17}$ & $3 \times 10^{-23}$ & $2 \times 10^{-7}$ & $5 \times 10^{-17}$ & $9 \times 10^{-23}$ & $6 \times 10^{-7}$ & $2 \times 10^{-16}$ & $3 \times 10^{-22}$ & $2 \times 10^{-6}$ \\
\hline $\begin{array}{l}\text { Roof fall }+ \text { release at depth } \\
\text { through leaky interbed }\end{array}$ & $7 \times 10^{-16}$ & $4 \times 10^{-19}$ & $5 \times 10^{-8}$ & $2 \times 10^{-15}$ & $9 \times 10^{-19}$ & $1 \times 10^{-7}$ & $1 \times 10^{-14}$ & $5 \times 10^{-18}$ & $6 \times 10^{-7}$ \\
\hline $\begin{array}{l}\text { Roof fall }+ \text { cavern seal } \\
\text { failure }+ \text { release at depth }\end{array}$ & $1 \times 10^{-17}$ & $2 \times 10^{-23}$ & $1 \times 10^{-7}$ & $3 \times 10^{-17}$ & $5 \times 10^{-23}$ & $4 \times 10^{-7}$ & $2 \times 10^{-16}$ & $3 \times 10^{-22}$ & $2 \times 10^{-6}$ \\
\hline $\begin{array}{l}\text { Roof fall }+ \text { cavern seal } \\
\text { failure }+ \text { release at shallow } \\
\text { depth }\end{array}$ & $1 \times 10^{-9}$ & $9 \times 10^{-16}$ & $7 \times 10^{-6}$ & $1 \times 10^{-8}$ & $8 \times 10^{-15}$ & $6 \times 10^{-5}$ & $2 \times 10^{-7}$ & $1 \times 10^{-13}$ & $1 \times 10^{-3}$ \\
\hline
\end{tabular}

" This is the risk from the chemical constituents of NORM waste. It is exactly the same as the risk from NOW as reported in Tomasko et al. (1997).

' This is the risk from the radiological constituents of NORM waste. 